\title{
Algae as New Kids in the Beneficial Plant Microbiome
}

OPEN ACCESS

Edited by:

loannis Stringlis,

Utrecht University, Netherlands

Reviewed by:

Ke Yu,

Henan University, China

Wu Xiong,

Utrecht University, Netherlands

*Correspondence:

Choong-Min Ryu

cmryu@kribb.re.kr

Specialty section:

This article was submitted to

Plant Symbiotic Interactions,

a section of the journal

Frontiers in Plant Science

Received: 28 August 2020

Accepted: 13 January 2021

Published: 04 February 2021

Citation:

Lee S-M and Ryu C-M (2021) Algae as New Kids in the Beneficial

Plant Microbiome.

Front. Plant Sci. 12:599742.

doi: 10.3389/fp/s.2021.599742

\author{
Sang-Moo Lee ${ }^{1,2,3}$ and Choong-Min Ryu ${ }^{1,2 *}$ \\ ${ }^{1}$ Molecular Phytobacteriology Laboratory, Infectious Disease Research Center, KRIBB, Daejeon, South Korea, ${ }^{2}$ Department \\ of Biosystems and Bioengineering, KRIBB School of Biotechnology, University of Science and Technology, Daejeon, \\ South Korea, ${ }^{3}$ Department of Applied Bioscience, Dong-A University, Busan, South Korea
}

Previously, algae were recognized as small prokaryotic and eukaryotic organisms found only in aquatic habitats. However, according to a recent paradigm shift, algae are considered ubiquitous organisms, occurring in plant tissues as well as in soil. Accumulating evidence suggests that algae represent a member of the plant microbiome. New results indicate that plants respond to algae and activate related downstream signaling pathways. Application of algae has beneficial effects on plant health, such as plant growth promotion and disease control. Although accumulating evidence suggests that secreted compounds and cell wall components of algae induce physiological and structural changes in plants that protect against biotic and abiotic stresses, knowledge of the underlying mechanisms and algal determinants is limited. In this review, we discuss recent studies on this topic, and highlight the bioprotectant and biostimulant roles of algae as a new member of the plant beneficial microbiome for crop improvement.

Keywords: microalgae, microbiome, Chlorella, cyanobacteria, plant immunity, plant growth promotion (PGP), biological control

\section{INTRODUCTION}

Algae is a group of ancient photosynthetic organisms ranging from prokaryotic cyanobacteria to eukaryotic microalgae (Parker et al., 2008). Generally, algae are classified mainly depending on their color, shape, and life cycle (Blaby-Haas and Merchant, 2019). Out of more than 800,000 species of algae that exist in nature, only 5,000 have been characterized to date. Out of 5,000 species, only small number of the algae species have been selected to determine their potential applications in plant growth under defined growth conditions. Algae are broadly classified as micro- and macroalgae based on size. Macroalgae indicates large aquatic photosynthetic plants that can be seen without the aid of a microscope and can generally be divided into three groups: Green (Chlorophyta), Red (Rhodophyta), and Brown-Kelps (Phaeophyta-related to Chromista). Microalgae comprise representative genera, including Arthrospira, Chlorella, Dunaliella, Nostoc, and Aphanizomenon (Elster, 2002). Prokaryotic microalgae, namely, cyanobacteria, play a critical role in the natural ecosystem, particularly in plant-microbe interactions. However, the idea that algae are a member of the plant-associated microbial community has long been debated (Berg et al., 2020). 


\section{DEFINITION AND MEMBERSHIP OF THE MICROBIOME}

It is important to understand the definition of the microbiome before discussing algae as a new member of the plant microbiome, since microbe and microbiome are distinct terminologies. Most scientists follow the definition of microbiome first provided by Whipps et al. (1988), according to which a microbiome "may be defined as a characteristic microbial community occupying a reasonably well defined habitat which has distinct physio-chemical properties. This term not only refers to the microorganisms involved but also encompasses their theater of activity" (Whipps et al., 1988). However, the definition of microbiome has been revised several times in the last $20+$ years to meet the technological and conceptual advances. "The microbiome is defined as a characteristic microbial community occupying a reasonable well-defined habitat which has distinct physio-chemical properties. The microbiome not only refers to the microorganisms involved but also encompass their theater of activity, which results in the formation of specific ecological niches. The microbiome, which forms a dynamic and interactive micro-ecosystem prone to change in time and scale, is integrated in macro-ecosystems including eukaryotic hosts, and here crucial for their functioning and health" (Berg et al., 2020).

Many microbiologists less considered algae and protists as members of the plant-associated microbiome (Longford et al., 2019; Wilpiszeski et al., 2019). However, most microbiologists agree that algae, except some macroalgae, are microorganisms based on their size and characteristics. In this review, we discuss only microalgae species, including both prokaryotic and eukaryotic organisms. The ecological niche of algae had also been debated. Here, we focus on algae as a member of the microbiome and their beneficial effects on plant fitness. To meet the minimum conceptual role, algae must exist on or around the plant surface and inside plant tissues.

\section{ALGAE AS MEMBERS OF THE SOIL MICROBIOME}

Because fresh and seawater were previously recognized as the habitat of algae, most microbiologists did not consider that algae could thrive in soil or on plant surfaces. However, more than 30 years ago, scientists investigated the distribution of algae in soil (Davey, 1989, 1991; Davey and Clarke, 1991). Early studies were conducted to identify cryptogrammic flora on the Antarctic fellfield soil based on their chlorophyll contents and microscopic observations. These studies revealed that Oscillatoriaceae was the dominant family in the soil, up to a depth of $8 \mathrm{~cm}$ below the soil surface (Davey and Clarke, 1991). Limitations of the classification on algal species based on conventional microbiological approaches, including isolation and in vitro culture on artificial media, led to the development of molecular techniques, including PCR-based 18S rDNA sequencing of the algae community in the soil (Bérard et al., 2005; Bradley et al., 2016; Khaw et al., 2020). In areas with harsh climatic conditions, such as semi-arid steppes, warm deserts, and polar regions, the algal community forms a biological soil crust along with other microorganisms to protect against abiotic and biotic stresses (Zhang et al., 2011; Pushkareva et al., 2016; Krug et al., 2020). Algae were also identified as active microbes in agricultural fields by $18 \mathrm{~S}$ rDNA sequencing (Bérard et al., 2005). For instance, four classes of algae were identified in soil samples collected from a vegetable field (depth: $0-15 \mathrm{~cm}$ ) in Nigeria: Chlorophyceae, Cyanophyceae, Bacillariophyceae, and Euglenophyceae (Adesalu and Olugbemi, 2015). Collectively, these studies suggest that algae are distributed across diverse environments, ranging from polar areas to agricultural fields. However, the interaction between land plants and algae has not been studied intensively. To utilize algae as plant health-promoting factors, it is important to understand the ecological niche of algae.

\section{ECOLOGICAL NICHE}

Previously, freshwater and seawater were considered as the ecological niches of algae, as described above. Considering algae as a member of the plant microbiome (phytobiome) has been debated because algae could not be isolated from the rhizosphere, phyllosphere, or endosphere (Gantar and Elhai, 1999; Gantar, 2000; Treves et al., 2016; Zhu et al., 2018). Moreover, the role of algae in plant fitness has not been evaluated extensively by biochemical and molecular analyses. Only recent studies demonstrate that algae are a member of the phytobiome. For instance, Chlorella species are found in the soil and on the plant leaf surface (Liu and Chen, 2016; Treves et al., 2016; Zhu et al., 2018), and cyanobacteria, such as Nostoc and Anabaena spp., were identified on the plant root surface (Gantar et al., 1991, 1995; Spiller et al., 1993; Gantar and Elhai, 1999; Gantar, 2000). However, recent microbiome analysis using the DNA sequence-based metagenome technology revealed that microalgae, including eukaryotic and prokaryotic (cyanobacteria) species, must be considered as members of the microbiome (Mendes et al., 2013; Xu et al., 2018). Microalgae have also been identified in the soil and in plant tissues (Leach et al., 2017). Previous studies on plant-algae interactions did not demonstrate the beneficial effects of algae on plant growth and defense. In this review, we focus on algae as a member of the beneficial microbiome and on their beneficial effects on plant health. Since the concept of 'beneficial microbiome' has not been defined clearly (Berg et al., 2020), beneficial algae could be categorized as having direct and indirect beneficial effects on plant, similarly to other beneficial microbes (e.g., PGPR). The bacterial and fungal inoculants on seeds, seedlings, and propagating plant materials secrete growth-enhancing compounds directly, which mimic plant hormones and promote increased plant growth and yield (Lugtenberg and Kamilova, 2009). The inoculants also promote plant growth by inhibiting pathogenic and deleterious plant-associated microbes and by activating plant innate immunity against plant pathogens; the latter represents an indirect effect of beneficial bacteria and fungi on plants. Another indirect effect of such inoculants is modulation of the microbiome, referred to as microbiome engineering (Dessaux et al., 2016). The direct and indirect effects 
of bacteria and fungi on plants are well known, but those of algae are a new emerging concept. Here, we summarize the beneficial effects of algae on crop plants in the greenhouse and field.

\section{PLANT ROOT COLONIZATION AND PARA-NODULE FORMATION}

Many species, ranging from moss to angiosperms, exhibit symbiotic interactions with algae (Meeks and Elhai, 2002; Santi et al., 2013). To interact with plants, algae must colonize the plant surface and cells within plant tissues, similar to other microbial organisms involved in symbiotic and mutualistic interactions with plants (Figure 1). Most examples of plant-algae interactions involve prokaryotic algae, i.e., cyanobacteria (Gantar and Elhai, 1999; Gantar, 2000; Treves et al., 2016; Zhu et al., 2018). Cyanobacteria can enter the plant through the stomata and colonize the intercellular space, forming loops and intracellular coils (Krings et al., 2009) (Figure 1). Anabaena spp. colonize the roots of wheat and cotton plants (Karthikeyan et al., 2009; Babu et al., 2015; Bidyarani et al., 2015) (Figure 1). Calothrix sp. was also found on the root system of wheat (Babu et al., 2015; Bidyarani et al., 2015). Beyond colonization of the root surface, Tolypothvix sp. and Leptolyghya sp. were detected in the intercellular space in Cycads plants (Cuddy et al., 2012) (Figure 1). Thus, the algae-plant interactions represent another example of a symbiotic relationship between the two organisms. A good example of this relationship is colonization of monocots, such as wheat and rice, by Nostoc spp. (Gantar et al., 1991; Ahmed et al., 2010; Hussain et al., 2013, 2015). Gantar et al. (1991) isolated diverse heterocystous nitrogen-fixing cyanobacteria, including Nostoc, Anabaena, and Cylindrospermum, from plant root and soil. Assessment of wheat seedling roots revealed two types of association patterns: loose colonization of root hair by Anabaena and tight colonization of the root surface within a restricted zone by Nostoc (Gantar et al., 1991) (Figure 1).

In addition to the free-living lifestyle on the plant root surface, Nostoc species also exist as endosymbionts in the flowering land plant (angiosperm) Gunnera (Silverster and Smith, 1969; Silvester, 1976; Lindblad et al., 1990). Cyanobacteria also form symbiotic relationships with other plant species, including bryophytes (e.g., Anthoceros), gymnosperms (e.g., Cycads), and water fern (Azolla) (Braun-Howland and Nierzwicki-Bauer, 1990; Lindblad et al., 1990; Meeks and Rai, 1990). Among these four multicellular plants, Gunnera L. develops well-organized, unique organs named glands through symbiosis with Nostoc (Bergman et al., 1992). Intriguingly, the glands of Gunnera are morphologically similar to crown galls formed by Agrobacterium tumefaciens. The detailed mechanisms by which the following processes happen, have been elucidated as gland morphology, cell penetration, intracellular colonization, hormogonium formation, gland development, and host specificity. During symbiosis, cyanobacteria influence nitrogen fixation and release, heterocyst development, and consistence of symbiosis. Glands formed by Nostoc on the stem of Gunnera plants are similar to nodules formed by Rhizobium spp. and crown gall formed by A. tumefaciens (Rasmussen et al., 1996). The Nostoc genome does not contain homologs of the two Agrobacterium genes required for T-DNA transfer-induced crown gall formation in plants, indicating that the mechanism of gland formation is distinct from that of gall formation. By contrast, the genome of Nostoc harbors homologs of the Rhizobium nod-box genes including nodEF, nodMN, and enoY. However, the induction of other critical nod genes, including nodABC, nodD1, and nodD2, and nod protein, could not be detected in Nostoc when treated with acidic mucilage secreted by stem glands (Rasmussen et al., 1996). These data indicate that Rhizobium-legume symbiosis is distinct from Gunnera-Nostoc symbiosis.

Scientists have attempted to form nodule-like structures and to functionally fix nitrogen in non-legume plants. Tchan and Kennedy (1989) succeeded in developing nodule-like structures, named para-nodules, using 2,4-dichlorophenoxy acetic acid (2,4D), a synthetic compound that mimics auxin, but they failed to fix nitrogen using nitrogenase-containing bacteria. Inoculation of Nostoc sp. strain 2S9B into the 2,4-D led para-nodule increased the acetylene reduction capacity by more than threefold compared with that of the untreated control (Gantar and Elhai, 1999) (Figure 1). In the absence of supplemental nitrogen, wheat shoot growth could be increased by co-inoculation with 2,4D and Nostoc sp. strain 2S9B (Gantar and Elhai, 1999; Gantar, 2000). Similarly, para-nodule formation and nitrogen fixation could also be induced in rice seedlings by treatment with 2,4D and Nostoc spp. (Nilsson et al., 2002). Two possibilities could explain why para-nodules do not occur naturally in land plants such as wheat and rice: (i) below-threshold levels of auxin, and (ii) lack of Nostoc spp. colonization on the wheat and rice tissues as the ecological niche (Figure 1). This can be used to identify specific Nostoc spp. that elicit para-nodule formation in land plants in near future. Intriguingly, unlike prokaryotic algae, it is not reported that eukaryotic algae colonize on plant tissues.

\section{ALGAE AS A NEW MEMBER OF THE BENEFICIAL PLANT MICROBIOME}

\section{Biological Control of Plant Pathogens}

Algal species have been used intensively for biological control of fungal pathogens (Figure 2 and Table 1). In tomato and cotton, root-drench application of prokaryotic Anabaena variabilis, Anabaena torulosa, Anabaena laxa, and Calothrix sp. reduced damping-off symptoms caused by Pythium debaryanum, Fusarium oxysporum, F. moniliforme, and Rhizoctonia solani (Prasanna et al., 2008, 2013; Chaudhary et al., 2012) (Figure 2 and Table 1). Additionally, the eukaryotic Chlorella fusca protects host plant against pathogenic fungi Colletotrichum orbiculare and Botrytis squamosa in cucumber and Chinese chive (Lee et al., 2016, 2017; Kim et al., 2018a). The cell extract or filtered supernatant of cyanobacteria and Chlorella species also exhibits biological control activity against $F$. oxysporum, P. aphanidermatum, and Sclerotinia sclerotiorum in tomato, pepper, and brinjal (Biondi et al., 2004; Kim and Kim, 2008; Manjunath et al., 2010). Algae can suppress fungal disease via two putative mechanisms. First mechanism involves inhibition of fungal pathogen growth (Figure 2 and Table 1). For 


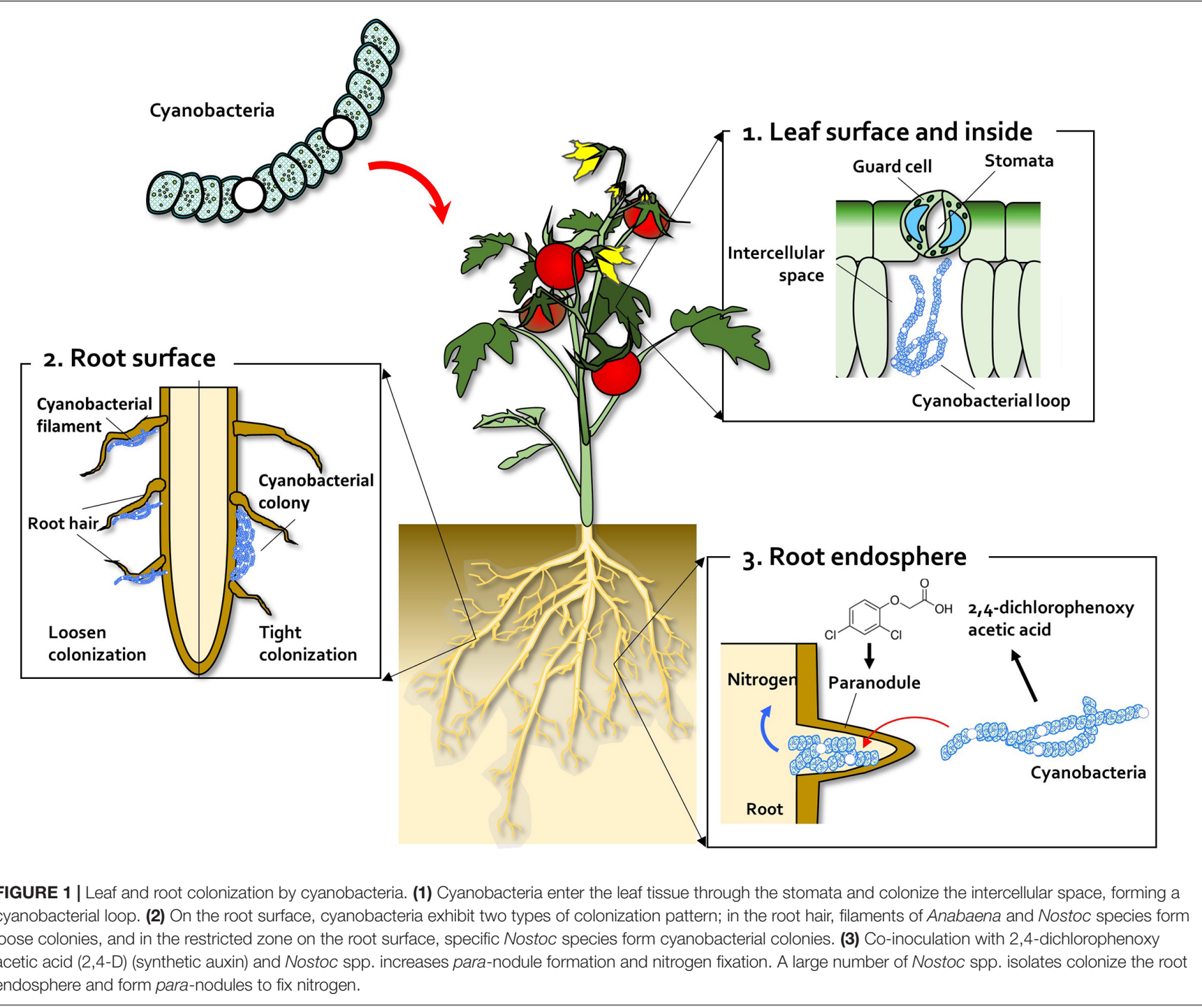

example, cyanobacteria Anabaena and Calothrix species showed antagonistic activity against Fusarium spp., Pythium spp., and Rhizotoctonia spp. in vitro (Chaudhary et al., 2012; Prasanna et al., 2013, 2016), and eukaryotic C. fusca also inhibited the growth of $C$. orbiculare hyphae in vitro and suppressed the formation of appressorium on cucumber leaves (Lee et al., 2016, 2017). The second mechanism involves activation of plant immune responses. C. fusca treatment showed antagonistic activity against $C$. orbiculare as well as the induction of defenserelated structural modifications such as cell wall thickness, vesicle accumulation, and sheath formation, in cucumber leaves (Kim et al., 2018b).

Microalgae species have also been used to control pathogenic nematodes and insect pests (Sathiyamoorthy and Shanmugasundaram, 1996; Choleva et al., 2005; Khan et al., 2005, 2007; Bileva, 2013; Hamouda and El-Ansary, 2013) (Figure 2 and Table 1). Root treatment of tomato with cyanobacteria such as Microcoleus vaginatus, Oscillatoria chlorine, Aphanocapsa albida, Anabaena oryzae, Nostoc muscorum, and Calothrix marchica reduced gall formation caused by Meloidogyne arenaria and M. incognita (Khan et al., 2005, 2007; Hamouda and El-Ansary, 2017). Soil-drench application of Chlorella vulgaris extract $(1 \mathrm{~g}$ per pot) reduced infestation of grapevine roots by Xiphinema index by 2-3fold compared with the untreated control (Choleva et al., 2005, 2007; Bileva, 2013). Foliar application of $0.01-0.1 \%$ peptides extracted from the cyanobacterium Scytonema MKU 106 reduced the feeding frequency of a chewing insect, Sylepta derogata, in cotton plants (Sathiyamoorthy and Shanmugasundaram, 1996). The algae species can protect host plant against pathogenic nematode and insect pests by nematocidal or repellent activity rather than as plant immune activation (Sathiyamoorthy and Shanmugasundaram, 1996; Choleva et al., 2007).

Compared with fungal pathogens and insect pests, biological control of bacterial pathogens using algae has remained largely unknown until 2020, when we reported for the first time the biological control of the bacterial pathogen Pseudomonas 


\section{Biological control}

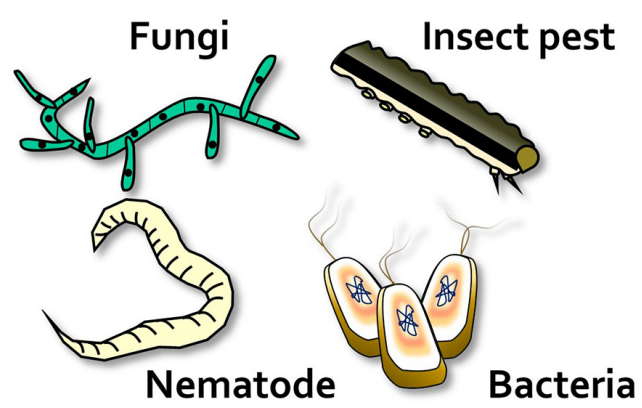

\section{Abiotic stress tolerance}
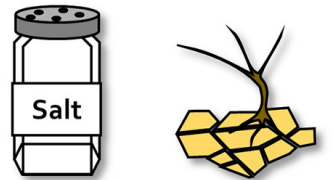

Salinity

Drought

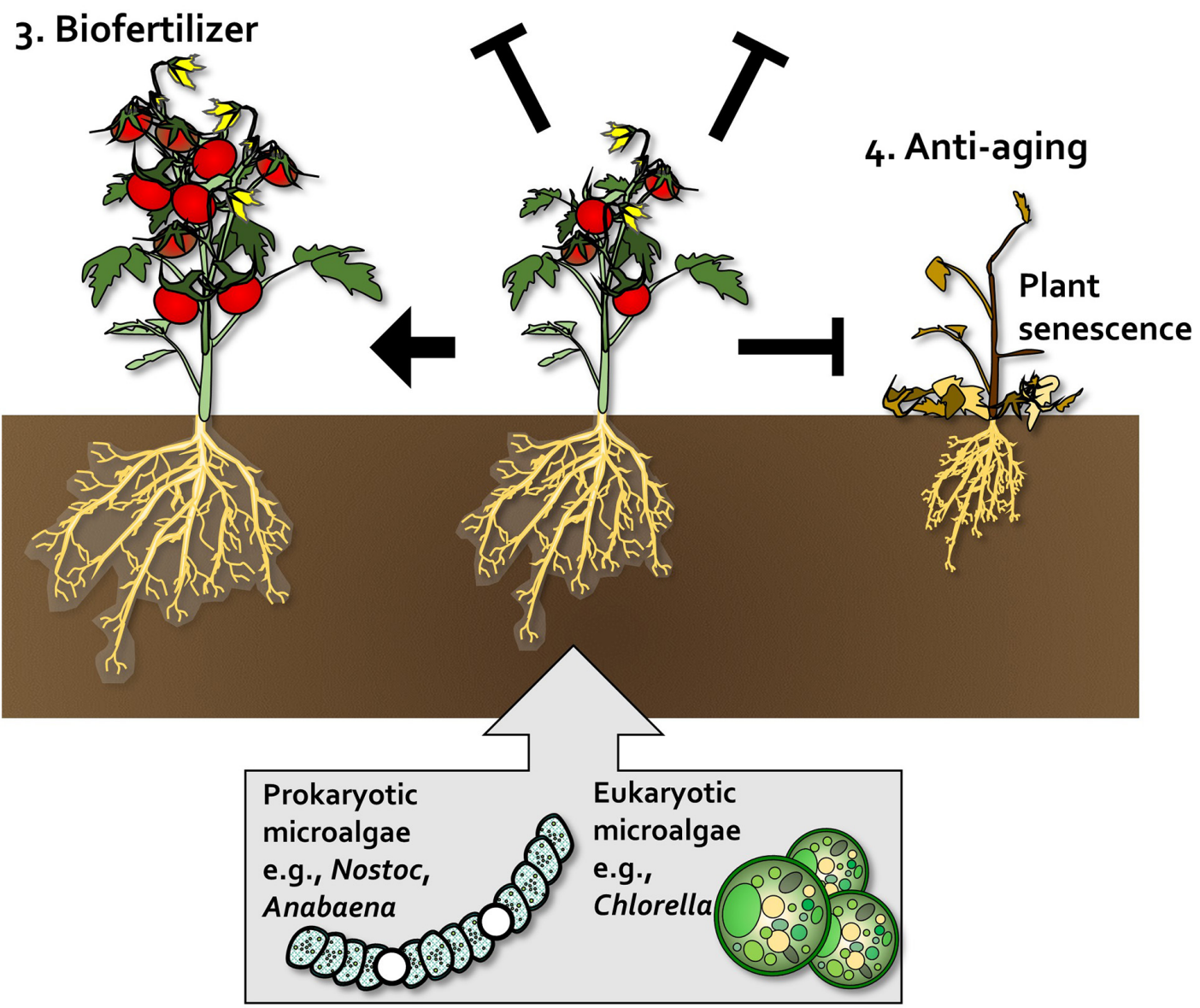

FIGURE 2 | Beneficial effects of algae on plants. In plants, prokaryotic microalgae such as Nostoc and Anabaena, and eukaryotic microalgae such as Chlorella, act as biological control agents (1), abiotic stress tolerance enhancers (2), biofertilizers that promote plant growth and crop yield (3), and anti-aging agents that delay senescence and enhance plant robustness (4).

syringae pv. tomato (Pto) by C. fusca in the model plant, Arabidopsis thaliana (Lee et al., 2020a, Figure 2 and Table 1). Foliar application of $C$. fusca culture $\left(10^{7}\right.$ cells $\left./ \mathrm{ml}\right)$ reduced the population of Pto in Arabidopsis leaves by 10-fold. Further investigation revealed that C. fusca and its determinant D-lactic acid prime plant innate immunity against Pto (Lee et al., 2020a). To the best of our knowledge, there have been no reports on the biocontrol activity of algae against phytopathogenic viruses.
Therefore, testing the potential application of algae against plant viruses is important.

\section{Induced Tolerance Against Abiotic Stresses}

The application of algae-derived substances could also increase tolerance against abiotic stresses (Figure 2 and Table 2). In 
TABLE 1 | Biological control of plant pathogens and insects using algal species.

\begin{tabular}{|c|c|c|c|c|c|c|c|}
\hline Group & $\begin{array}{l}\text { Algae } \\
\text { species/consortia }\end{array}$ & Pathogen/insect type & $\begin{array}{l}\text { Pathogen/insect } \\
\text { name }\end{array}$ & Host plant & Treatment method & Product applied & References \\
\hline \multirow[t]{9}{*}{$\begin{array}{l}\text { Prokaryotic } \\
\text { cyanobacteria }\end{array}$} & $\begin{array}{l}\text { Anabaena variabilis } \\
\text { RPAN59, Anabaena } \\
\text { laxa RPAN8 }\end{array}$ & Fungal pathogen & $\begin{array}{l}\text { Pythium debaryanum, } \\
\text { Fusarium oxysporum f. } \\
\text { sp. lycopersici, } \\
\text { Fusarium moniliforme, } \\
\text { and Rhizoctonia solani }\end{array}$ & Tomato & Soil application & $\begin{array}{l}\text { Cell culture and filtered } \\
\text { supernatant }\end{array}$ & $\begin{array}{l}\text { Chaudhary et al., } \\
\text { 2012; Prasanna } \\
\text { et al., } 2013\end{array}$ \\
\hline & $\begin{array}{l}\text { Anabaena torulosa, } A \\
\text { laxa, Calothrix sp. }\end{array}$ & Fungal pathogen & R. solani & Cotton & Soil application & Cell culture & $\begin{array}{l}\text { Prasanna et al., } \\
2016\end{array}$ \\
\hline & $\begin{array}{l}\text { Nostoc commune } \\
\text { FA-103 }\end{array}$ & Fungal pathogen & $\begin{array}{l}\text { F. oxysporum f. sp. } \\
\text { lycopersici }\end{array}$ & Tomato & Seed coating & Cell extract & Kim and Kim, 2008 \\
\hline & Calothrix elenkenii & Fungal pathogen & $\begin{array}{l}\text { Pythium } \\
\text { aphanidermatum }\end{array}$ & $\begin{array}{l}\text { Tomato, chili, } \\
\text { and brinjal }\end{array}$ & Seed soaking & Filtered supernatant & $\begin{array}{l}\text { Manjunath et al., } \\
2010\end{array}$ \\
\hline & $\begin{array}{l}\text { Nostoc strain ATCC } \\
53789\end{array}$ & Fungal pathogen & Sclerotinia sclerotiorum & Tomato & Seed soaking & $\begin{array}{l}\text { Cell biomass and } \\
\text { methanolic extract }\end{array}$ & Biondi et al., 2004 \\
\hline & Microcoleus vaginatus & Pathogenic nematode & Meloidogyne arenaria & Tomato & Root dipping & Filtered supernatant & Khan et al., 2005 \\
\hline & Oscillatoria chlorina & Pathogenic nematode & M. arenaria & Tomato & Soil application & Dried cell suspension & Khan et al., 2007 \\
\hline & $\begin{array}{l}\text { Aphanocapsa albida, } \\
\text { Anabaena oryzae, } \\
\text { Nostoc muscorum, and } \\
\text { Calothrix marchica }\end{array}$ & Pathogenic nematode & Meloidogyne incognita & Tomato & Soil application & Aqueous extract & $\begin{array}{l}\text { Hamouda and } \\
\text { El-Ansary, } 2013\end{array}$ \\
\hline & Scytonema MKU 106 & Chewing insect & $\begin{array}{l}\text { Helicoverpa armigera, } \\
\text { Heliothis larvae, and } \\
\text { Sylepta derogata }\end{array}$ & Cotton & Foliar application & Peptide extract & $\begin{array}{l}\text { Sathiyamoorthy } \\
\text { and } \\
\text { Shanmugasundaram, } \\
1996\end{array}$ \\
\hline \multirow[t]{4}{*}{ Eukaryotic green algae } & Chlorella vulgaris & Pathogenic nematode & $\begin{array}{l}\text { M. arenaria and } \\
\text { Xiphinema indexin }\end{array}$ & Tomato, grape & Soil application & Dried cell extract & $\begin{array}{l}\text { Choleva et al., } \\
\text { 2005; Bileva, } 2013\end{array}$ \\
\hline & Chlorella fusca & Fungal pathogen & $\begin{array}{l}\text { Colletotrichum } \\
\text { orbiculare }\end{array}$ & Cucumber & Foliar application & Cell culture & $\begin{array}{l}\text { Lee et al., 2016, } \\
\text { 2017; Kim et al., } \\
\text { 2018a }\end{array}$ \\
\hline & C. fusca & Fungal pathogen & Botrytis squamosa & Chinese chives & Foliar or soil application & Cell culture & Kim et al., 2018b \\
\hline & C. fusca & Bacterial pathogen & $\begin{array}{l}\text { Pseudomonas syringae } \\
\text { pv. tomato }\end{array}$ & Arabidopsis & Foliar application & $\begin{array}{l}\text { Cell culture/cell-free } \\
\text { supernatant }\end{array}$ & Lee et al., 2020a \\
\hline $\begin{array}{l}\text { Cyanobacteria-bacteria } \\
\text { consortia }\end{array}$ & $\begin{array}{l}\text { Anabaena oscillarioides } \\
\text { and Bacillus subtilis }\end{array}$ & Fungal pathogen & $\begin{array}{l}\text { F. oxysporum, } P \text {. } \\
\text { debaryanum, } P \text {. } \\
\text { aphanidermatum, and } \\
\text { R. solani }\end{array}$ & Tomato & Soil application & Cell culture & Dukare et al., 2011 \\
\hline
\end{tabular}




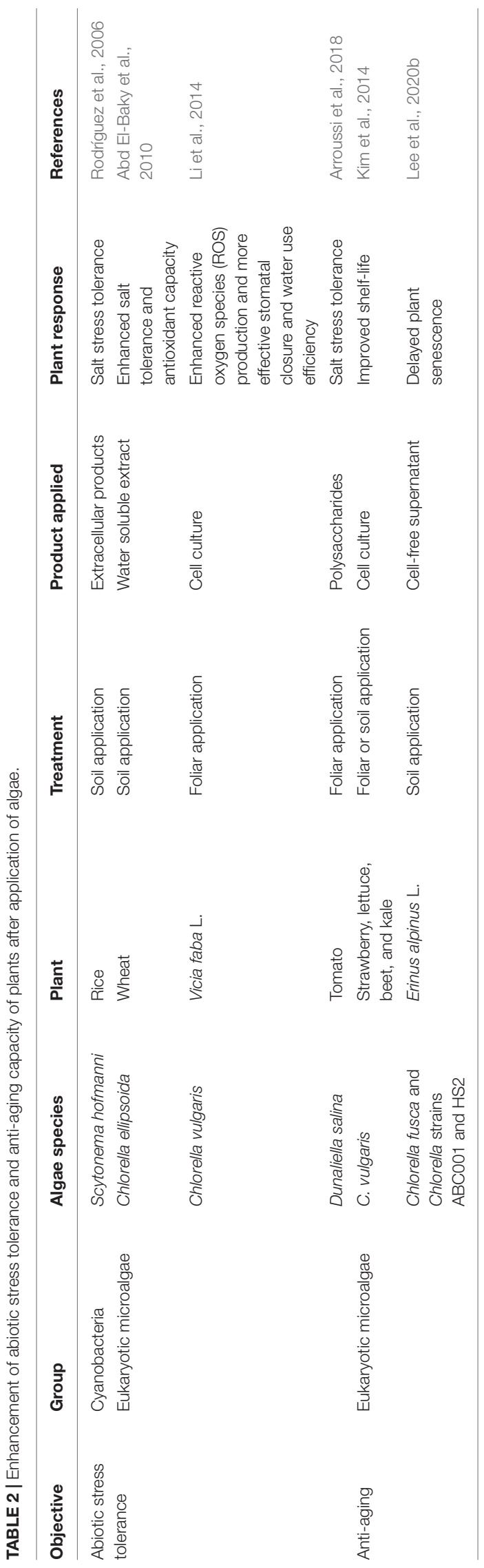

rice, extracellular products of the cyanobacterium Scytonema hofmanni nullified the effects of salt stress $(<5 \mathrm{~g} / \mathrm{ml} \mathrm{NaCl})$ on dry weight and length of shoot (Rodríguez et al., 2006). Under high salt stress, tomato plants treated with $1 \%$ Dunaliella salina hydrolyzate via spray application showed higher shoot dry weight, root dry weight, and chlorophyll $\mathrm{a}$ and $\mathrm{b}$ content than untreated plants (Arroussi et al., 2018), and soil treatment with water-soluble extracts of Chlorella ellipsoida and Spirulina maxima increased the total protein content of wheat grain by 1.4-fold compared with the control (Abd El-Baky et al., 2010). Moreover, treatment of fava bean plants with C. vulgaris culture induced drought tolerance (Li et al., 2014). Abiotic stress tolerance triggered by microalgae treatment is mostly linked to production of reactive oxygen species (ROS) and antioxidant activity in plants (Li et al., 2014; Arroussi et al., 2018). In tomato and bean, foliar application of $D$. salina extracts and C. vulgaris activated antioxidant enzymes such as peroxidase (POD), superoxide dismutase (SOD), catalase (CAT), and ascorbate peroxidase (APX) (Li et al., 2014; Arroussi et al., 2018). Similarly, in bean plants, treatment with C. vulgaris culture increased stomata closure frequency and water use efficiency, thereby reducing transpiration and increasing drought tolerance (Li et al., 2014). However, further investigation of exact molecular mechanism and algal determinant for improving abiotic stress tolerance in plant will be required.

\section{Algae as Biofertilizers}

Prokaryotic cyanobacteria have been applied to monocots and dicots as biofertilizers to increase plant growth and crop yield (Figure 2 and Table 3). For example, rice plants treated with A. variabilis and Nostoc sp. VICCRI via root-drench application showed greater plant height, leaf length, and grain yield than inorganic fertilizer (Singh and Datta, 2007; Innok et al., 2009). Inoculation with A. laxa and Calothrix elenkinii increased the germination of coriander seeds and promoted root and shoot growth in coriander, cumin, and fennel (Kumar et al., 2013). Soaking of seeds in a solution of Spirulina platensis $\left(2 \times 10^{4}\right.$ cells $/ \mathrm{ml}$ ) increased the fresh and dry weight, height, and root length of crop plants, including rocket, Bayam red, and Pak choi, by 1.2-3-fold compared with the untreated control (Wuang et al., 2016). In addition, filtrated supernatant of cyanobacteria Calothrix sp., Hapalosiphon sp., Nostoc sp., and Westiellopsis sp., increased coleoptile and radicle length and seed germination in wheat by 2. 7-, 2. 1-, and 1.1-fold, respectively, compared with the sterile water control (Karthikeyan et al., 2009). Interestingly, treatment with multiple species of nitrogen-fixing cyanobacteria has a greater impact on plant growth, probably via synergistic effects on nutrient production (Karthikeyan et al., 2007; Paudel et al., 2012).

Similar to cyanobacteria, eukaryotic Chlorella spp. increased the growth of Perilla, onion, lettuce, Chinese cabbage, radish, turnip, and spinach plants when applied to roots and leaves (Kim et al., 2012, 2018a) (Figure 2 and Table 3). Seed treatment with C. vulgaris promoted germination and shoot and root weights in lettuce, tomato, and cucumber (Faheed and Fattah, 2008; Bumandalai and Tserennadmid, 2019). In the field, rootdrench application of Chlorella pyrenoidosa increased the 
TABLE 3 | Plant growth promotion following algal treatment.

\begin{tabular}{|c|c|c|c|c|c|}
\hline Group & Algae species & Host plant & Treatment & Product applied & References \\
\hline & $\begin{array}{l}\text { Anabaena laxa and Calothrix } \\
\text { elenkinii }\end{array}$ & $\begin{array}{l}\text { Coriander, cumin, and } \\
\text { fennel }\end{array}$ & Soil application & Cell culture & Kumar et al., 2013 \\
\hline \multirow{8}{*}{$\begin{array}{l}\text { Eukaryotic green } \\
\text { algae }\end{array}$} & Chlorella vulgaris & Wheat & Foliar application & Water soluble extract & Shaaban, 2001a \\
\hline & C. vulgaris & Maize & Soil application & Water soluble extract & Shaaban, 2001b \\
\hline & C. vulgaris & Lettuce & Soil application & Dried cell extract & $\begin{array}{l}\text { Faheed and Fattah, } \\
2008\end{array}$ \\
\hline & C. vulgaris & Tomato and cucumber & Seed soaking & Cell culture & $\begin{array}{l}\text { Bumandalai and } \\
\text { Tserennadmid, } 2019\end{array}$ \\
\hline & Chlorella fusca & $\begin{array}{l}\text { Barely, wheat, lettuce, } \\
\text { pepper, melon, } \\
\text { cucumber, perilla, } \\
\text { onion, radish, and } \\
\text { turnip }\end{array}$ & Soil application & Cell culture & Kim et al., 2012 \\
\hline & C. fusca & Spinach & Foliar or soil application & Cell culture & Kim et al., 2018b \\
\hline & Chlorella pyrenoidosa & Soybean & Soil application & Cell culture & $\begin{array}{l}\text { Dubey and Dubey, } \\
2010\end{array}$ \\
\hline & Chlorococcum infusionum & Tomato & Hydroponic system & $\begin{array}{l}\text { Co-cultivation with } \\
\text { plant }\end{array}$ & Zhang et al., 2017 \\
\hline $\begin{array}{l}\text { Microalgae } \\
\text { consortia }\end{array}$ & $\begin{array}{l}\text { Nostoc, Anabaena, Westiellopsis, } \\
\text { Aulosira, and Scytonema }\end{array}$ & Rice & Soil application & Cell culture & Paudel et al., 2012 \\
\hline \multirow{3}{*}{$\begin{array}{l}\text { Cyanobacteria- } \\
\text { other microbe } \\
\text { consortia }\end{array}$} & $\begin{array}{l}\text { Unidentified cyanobacteria and } \\
\text { rhizobacteria }\end{array}$ & Wheat & Soil application & Cell culture & Nain et al., 2010 \\
\hline & $\begin{array}{l}\text { Anabaena oscillarioides CR3, } \\
\text { Brevundimonas diminuta PR7, and } \\
\text { Ochrobactrum anthropi PR10 }\end{array}$ & Rice & Soil application & Cell culture & Rana et al., 2015 \\
\hline & A. torulosa and Trichoderma viride & Maize & Soil application & Extracted biofilms & Sharma et al., 2020 \\
\hline
\end{tabular}

shoot weight and grain yield of soybean plants by 70 and $53 \%$, respectively, compared with control plants (Dubey and Dubey, 2010). Cell extracts of C. vulgaris and dried biomass suspension of Nannochloropsis oculata showed plant growthpromoting activity in wheat, maize, tomato, and sugar beet (Shaaban, 2001a,b; Coppens et al., 2016; Barone et al., 2018). Interestingly, recent studies show that co-cultivation of sugar beet and tomato plants with C. vulgaris, Chlorococcum infusionum, and Scenedesmus quadricauda using the hydroponic system simultaneously increases the biomass of both the host plant and eukaryotic algal species (Zhang et al., 2017; Barone et al., 2018, 2019).

\section{Plant Anti-aging Agents}

Treatment with algae or algal solution also affect plant senescence (Figure 2 and Table 2). The ability to prolong plant development and delay the onset of age-related phenotypes is economically important in crop science and critical for fundamental plant research (Lim et al., 2007; Shahri and Tahir, 2014). During 
initial development of this anti-aging method, treatment with beneficial bacteria such as Pseudomonas spp. and Bacillus spp. was used to delay plant senescence (Ali et al., 2012; Carlson et al., 2015; Kuan et al., 2016; Naing et al., 2017). Interestingly, spray and irrigation application of $C$. vulgaris culture prolonged the shelf-life of strawberry, lettuce, beet, and kale (Kim et al., 2014). In addition, we reported that root-drench application of the cell-free supernatant of C. fusca, Chlorella sp. HS2 and Chlorella sp. ABC001, delayed shoot and flower senescence by up to 4 weeks in the ornamental flowering plant Erinus alpinus (Lee et al., 2020b). Given that other beneficial bacteria modulate ethylene signaling in plants (Ali et al., 2012; Carlson et al., 2015; Kuan et al., 2016; Naing et al., 2017), it is possible that microalgae suppress the ethylene signaling or biosynthesis pathway in plants. The detailed mechanism by which Chlorella mediates anti-aging effects in plants is, however, largely unknown.

\section{ALGAL DETERMINANTS OF PLANT HEALTH}

\section{Inhibitory Compounds Effective Against Pathogenic Microbes and Insect Pests}

Like classic bacterial biocontrol agents, beneficial algae produce antimicrobial compounds that suppress bacterial and fungal plant pathogen (Figure 3). For example, 4,4'-dihydroxybiphenyl, norharmane prokaryotic algae Nodularia spp. and Nostoc spp. and Nostoc insulare produces 4,4'-dihydroxybiphenyl, norharmane, and diterpenoids, which exhibit antibacterial activity against Escherichia coli and Pseudomonas aeruginosa, Bacillus subtilis, B. cereus, Staphylococcus epidermdis (Jaki et al., 2000; Volk and Furkert, 2006). In addition, cyanobacteria Anabaena spp., Chlorella spp., and Scenedesmus spp., produced siderophore as micronutrient ferric and copper ion chelators (McKnight and Morel, 1980; Goldman et al., 1983; Benderliev, 1999; Benderliev et al., 2003). Siderophores produced by microbes, especially such as Pseudomonas spp., were known as antimicrobial compounds and biological control agents in plants via chelating ferric iron, which can compete with bacterial pathogens for iron ions (Kloepper et al., 1980; Duijff et al., 1993; Lemanceau and Alabouvette, 1993). On the other hand, prokaryotic algae cyanobacteria can produce fungal cell wall-degrading enzymes including chitosanase, $\beta$-1,4-glucanase, $\beta$-1,3-glucanase, and benzoic acid, which can suppress growth of Fusarium sp., Penicillium sp., and Candida sp. (López et al., 2002; Chaudhary et al., 2012; Natarajan et al., 2012; Prasanna et al., 2013, 2016). Thus, further identification of microalgal antimicrobial compounds, and their biological control activity, is needed.

In addition to antimicrobial substances, cyanobacteria also produce pesticidal and nematocidal secondary metabolites, referred to as cyanotoxins (Hamouda and El-Ansary, 2017) (Figure 3). Cyanotoxins function as neurotoxins and hepatotoxins in animals (Sathiyamoorthy and Shanmugasundaram, 1996; Holajjer et al., 2013). The neurotransmitter-mimicking cyanotoxin, anatoxin-a, binds to eukaryotic nematode receptors and triggers continuous muscle contraction, causing muscle fatigue, and immobility (Carmichael, 1994; Dow and Swoboda, 2000; Mankiewicz et al., 2003). Moreover, cyanobacteria Microcystis spp. produce hepatotoxins including microcystins and nodularin (Holajjer et al., 2013), which inhibit the host metabolic system; for example, nodularin produced by Nodularia spumigena inhibit protein phosphatase activity in animal cells (Ohta et al., 1994). Additionally, cyanobacteria also produce peptide toxins that act as repellents (Sathiyamoorthy and Shanmugasundaram, 1996); for example, Anabaena and Scytonema species produce a low molecular weight $(<12 \mathrm{kDa})$ peptide toxin (Konst et al., 1965; Sathiyamoorthy and Shanmugasundaram, 1996). Interestingly, Scytonema-derived peptide toxin acts as a repellent due to its strong smell, and reduces the population size of chewing insects Helicoverpa armigera and Stylepta derogate on cotton leaves (Sathiyamoorthy and Shanmugasundaram, 1996). Collectively, these reports suggest that algal substances can inhibit phytopathogenic bacteria, fungi, pests, and nematodes directly. However, most of these algal compounds exhibit antagonistic activity against phytopathogens only in vitro. Thus, it is important to verify the activity of purified algal compounds in planta.

\section{Plant Hormone-Mimicking Compounds}

The plant growth-promoting microalgae, including prokaryotic cyanobacteria and eukaryotic microalgae, produce phytohormones such as auxin and cytokinin, which affect plant growth and development (Werner et al., 2001; Benjamins and Scheres, 2008).

Auxin regulates plant developmental processes including gametogenesis, embryogenesis, seedling growth, vascular patterning, and flower development (Hamann et al., 2002; Dimitrov and Zucker, 2006; Pagnussat et al., 2009). Auxins, including indole-3-acetic acid (IAA), indole-3-butyric acid (IBA), indole-3-propionic acid (IPA), and 3-methylindole, have been detected in diverse microalgae species (Misra and Kaushik, 1989; Mazur et al., 2001; Stirk et al., 2002, 2013; Karthikeyan et al., 2009; Hashtroudi et al., 2013). Interestingly, algal auxin seems to positively regulate plant-algae interactions (Figure 3). IAA produced by Nostoc species promotes plant growth in wheat and rice; a Nostoc mutant lacking the IAA biosynthesis gene, which encodes indole pyruvate decarboxylase, failed to promote plant growth (Hussain et al., 2013, 2015). In addition to plant growth promotion, algal auxin is also tightly linked with the ability of microalgae to colonize host roots (Ahmed et al., 2010; Hussain et al., 2013, 2015). Auxin production in Leptolyngbya sp. MMG1, Chroococcidiopsis sp. MMG-5, and Synechocystis sp. MMG-8, was increased during their colonization of plant roots (Ahmed et al., 2010). Strikingly, the lack of indole pyruvate decarboxylase significantly reduced colonization of rice and wheat roots by Nostoc species (Hussain et al., 2013, 2015). Collectively, algal auxin might act as a putative signaling molecule that mediates plant-microalgae interactions.

Cytokinin promote division and differentiation of plant cells, especially in apical and axillary meristems, and development of 


\section{A Inhibitory compounds against phytopathogens}

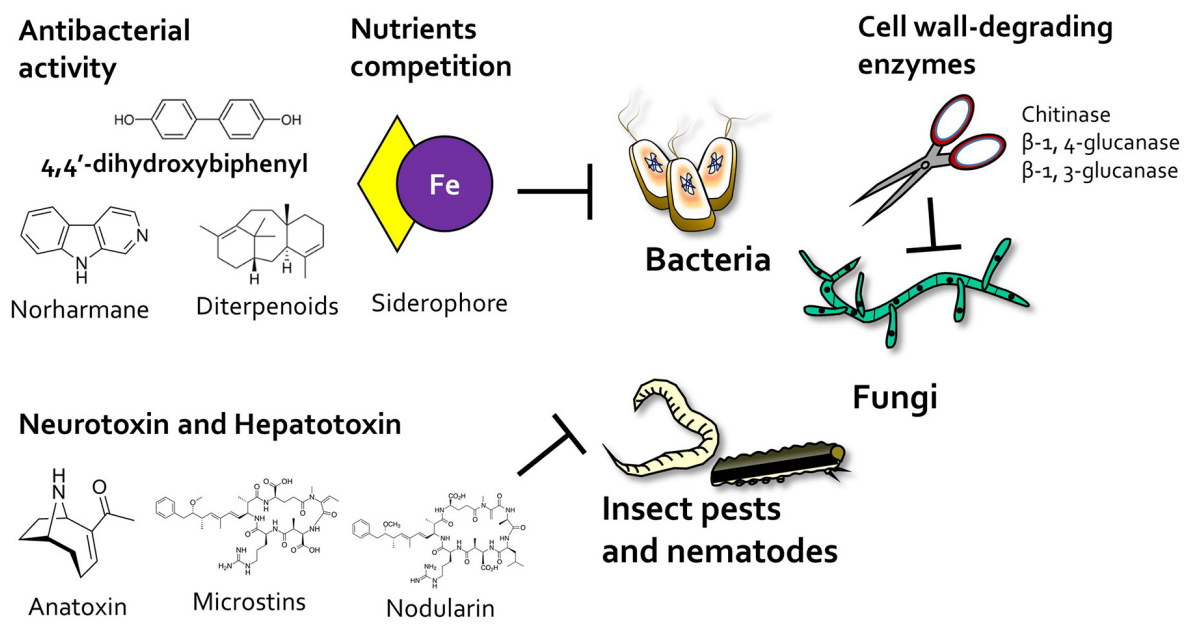

\section{B Mimic phytohormones}

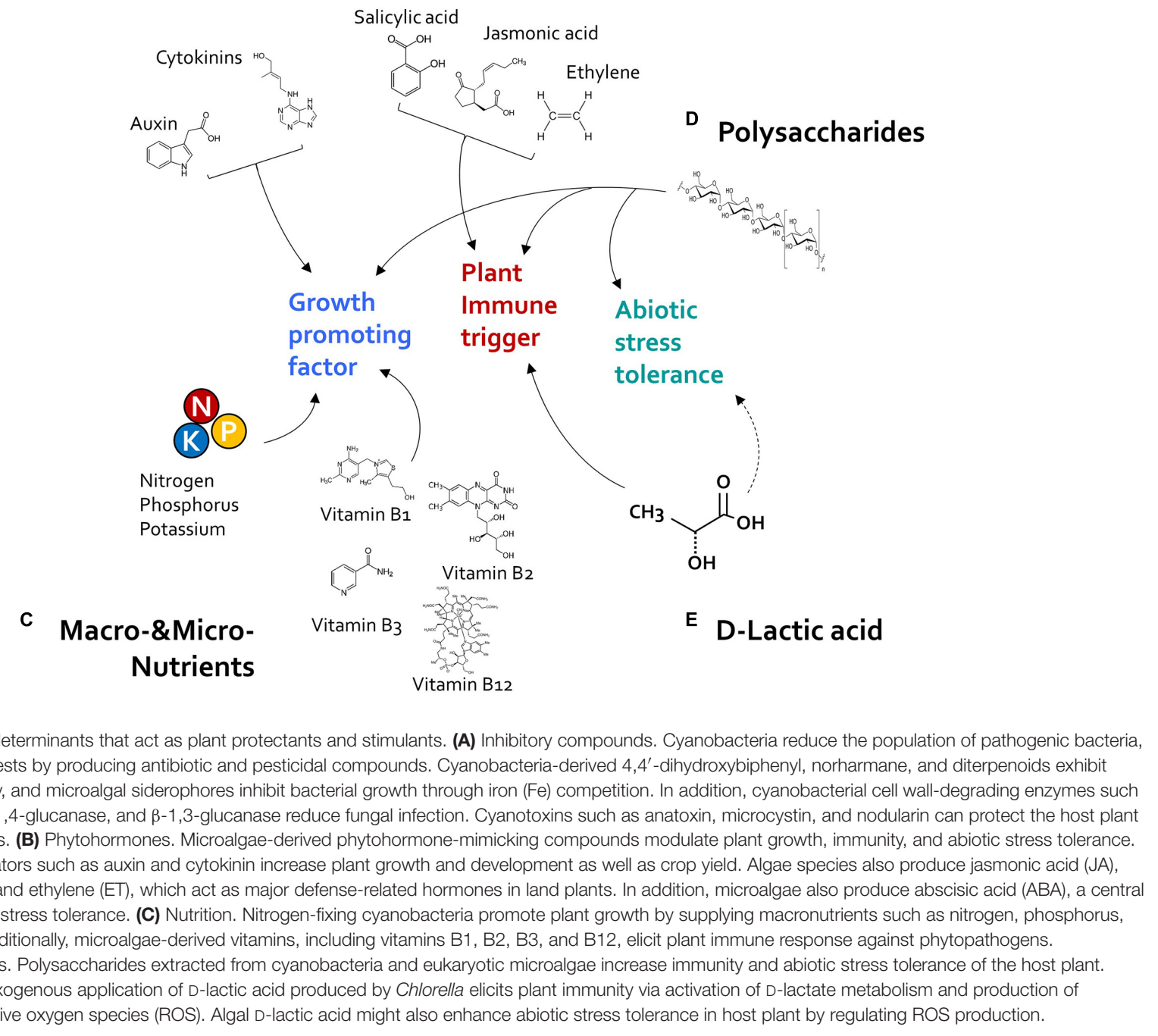


gynoecium, and female gametophyte (Marsch-Martínez et al., 2012; Cheng et al., 2013; Schaller et al., 2014). Cytokinin compounds, including trans-zeatin, cis-zeatin, zeatin riboside, dihydrozeatin riboside, topolin, and zeatin-o-glucoside, were produced by many microalgae species (Stirk et al., 2002, 2013; Tsavkelova et al., 2006; Hussain et al., 2010; Hussain and Hasnain, 2011). Similar with auxin, algal cytokinin also positively regulated plant growth promotion and root colonization (Figure 3). Knockout mutant of the cytokinin biosynthesis gene, which encodes isopentenyl transferase, in the plant growthpromoting cyanobacterium Nostoc AHM-12 failed to increase plant growth, and significantly reduced root colonization in rice and wheat (Hussain et al., 2013). Thus, in addition to auxin, understanding the molecular basis of how algal-derived cytokinin influence plant-algae interactions will be an interesting topic for future research.

In addition to growth-promoting phytohormone, defenserelated hormones such as jasmonic acid (JA), salicylic acid (SA), and ethylene (ET) are produced by algae species (Rodgers et al., 1979; Kreslavsky et al., 1997; Tsavkelova et al., 2006; Natarajan et al., 2012). Plant immunity can be activated systemically by PGPR, depending on JA, SA, and ET signaling (Pieterse et al., 1998, 2014; De Meyer et al., 1999; Kloepper et al., 2004; van Loon et al., 2006) (Figure 3). In addition, algae treatment can also induce activation of defense hormone signaling in host plant. Foliar application of the supernatant of C. fusca activates SA and JA signaling upon pathogen inoculation in Arabidopsis (Lee et al., 2020a). Similarly, treatment with liquid extracts of eukaryotic Tetraselmis sp., D. salina, N. gaditana, Aphanothece sp., and $A$. maxima induce the accumulation of the JA precursor, linolenic acid, in tomato (Mutale-joan et al., 2020). Thus, plant immunity triggered by algae is tightly involved in activation of defense-related hormonal signaling.

\section{Polysaccharides}

Algae produce diverse polysaccharides as cell wall components. Given their medical and cosmetic applications, algal polysaccharides are recognized as important substances (Figure 3). To utilize polysaccharides to improve plant health, studies have been conducted to gain molecular insight into the role of agal polysaccharides in plant protection (Arroussi et al., 2018; Farid et al., 2019). Bacterial and fungal polysaccharides such as lipopolysaccharides (LPSs) and EPSs are plant immune elicitors (Erbs and Newman, 2003; Park et al., 2008). Sulfated EPSs produced by $D$. salina increase salt stress tolerance, expression of genes encoding antioxidant enzymes (CAT, POD, and SOD), and accumulation of JA precursor in tomato (Arroussi et al., 2018). Crude polysaccharides extracted from Chlorella vulgaris, Chlorella sorokiniana, and Chlamydomonas reinhardtii increase expression of $P R$ genes and genes encoding antioxidant enzymes such as $\beta$-1,3-glucanase, APX, and POD in tomato plants (Farid et al., 2019).

In addition to immune activation, algal polysaccharides can also improve the growth and abiotic stress tolerance of host plants. The application of algal polysaccharides extracted from cyanobacterium S. platensis and A. platensis, and eukaryotic D. salina and Porphorydium sp. promoted shoot and root growth in in tomato and pepper (Elarroussia et al., 2016; Rachidi et al., 2020). Moreover, spray treatment of polysaccharides extracted from D. salina increased the shoot dry weight, and root dry weight of tomato plants by 1.8- and 5. 5-, respectively, under high salt stress compared with untreated plants (Arroussi et al., 2018), implying that algal polysaccharides enhance salt tolerance. Compared with microalgae polysaccharides, macroalgal polysaccharides such as carrageenans and betaglucans (laminarin, ulvan, and fucan) mainly function as biostimulants and bioprotectants (Mercier et al., 2001; Sangha et al., 2010, 2015; Vera et al., 2012; Ghannam et al., 2013; Shukla et al., 2016; Pettongkhao et al., 2019; Zou et al., 2019). However, the structure of microalgal polysaccharides is largely unknown. Thus, to elucidate the mode of action of microalgal polysaccharides in plants, it is important to identify the main determinant(s) in crude polysaccharide algal extracts.

\section{D-lactic Acid}

D-lactic acid is a major compound produced by Chlorella species (Gruber et al., 1974; Lee et al., 2020a). Recently, Dlactic acid in the supernatant of C. fusca was identified as a determinant of plant immunity against Pseudomonas syringae pv. tomato DC3000 in Arabidopsis (Lee et al., 2020a) (Figure 3). Especially, foliar application of D-lactic acid primed production of ROS after flagellin 22 (flg22) treatment in Arabidopsis (Lee et al., 2020a). Primed ROS production by D-lactic acid might be correlated with D-lactate oxidation and mitochondrial ROS (mtROS) production. D-lactic acid is metabolized by the D-lactate dehydrogenase (D-LDH), which localizes to the intermembrane space of mitochondria (Atlante et al., 2005; Welchen et al., 2016). Activation of D-LDH correlates strongly with activation of mitochondrial antioxidant enzyme (Husic and Tolbert, 1987). In Arabidopsis, exogenous application of D-lactic acid increases expression of D-LDH, cytochrome c oxidase subunit 2 (COX2), and alternative oxidase 1 (AOX1) in flg22-treated Arabidopsis (Lee et al., 2020a). These mitochondrial antioxidant enzymes might be activated to catalyze mtROS produced by D-lactic acid. Thus, microalgal-derived D-lactic acid enhances plant innate immunity and production of mtROS in plant.

The activation of D-LDH by D-lactic acid can also affect abiotic stress tolerance via methylglyoxal (MG) detoxification (Figure 3). MG is a cytotoxic compound generated as a byproduct of glycolysis, which accumulates under abiotic stress conditions (Maurino and Engqvist, 2015). To detoxify the accumulated MG, plants activate the expression of $\mathrm{D}-L D H$, which encodes the last enzyme in the MG detoxification pathway (Maurino and Engqvist, 2015). Recently, studies showed that D-LDH-mediated MG detoxification correlates with abiotic stress tolerance in yeast, sorghum, and rice (An et al., 2017; Jain et al., 2018, 2020; Bhowal et al., 2020). In sorghum, the expression of D-LDH1-4 genes was activated under heat, cold, salt, and drought stress conditions (Bhowal et al., 2020). In rice, D-LDH RNA interference (RNAi) plants were more sensitive to salt stress $(200 \mathrm{mM} \mathrm{NaCl})$ than wild-type plants (An et al., 2017). However, overexpression of $\mathrm{D}-\mathrm{LDH} 2$ conferred tolerance to multiple abiotic stresses, including salt stress, oxidative stress, osmotic stress, and heat stress in rice plants (Jain et al., 2020). Thus, microalgae-derived 
D-lactic acid might alleviate abiotic stress tolerance in plants via D-LDH-mediated MG detoxification.

\section{Plant Macro- and Micronutrients}

Algae have been utilized as a source of macro- and micronutrients for plants (Figure 3). Microalgae cyanobacteria possess specialized cells called heterocysts, which can fix atmospheric nitrogen (Singh and Bisoyi, 1989; Gantar et al., 1993; Karthikeyan et al., 2007; Babu et al., 2015). Thus, inoculation of soil with nitrogen-fixing cyanobacteria enhanced plant growth by increasing the availability of nitrogen, carbon, and vitamins (Tripathi et al., 2008; Prasanna et al., 2009; Renuka et al., 2016). In addition, application of microalgae consortium comprising Chlorella, Scenedesmus, Chlorococcum, Chroococcus, Phormidium, Anabaena, Westiellopsis, Nostoc, Aulosira, and Scytonema to soil enhanced the content of available nitrogen, phosphorus, and potassium (Paudel et al., 2012; Renuka et al., 2016).

Algae also secrete vitamins, which promote plant growth and plant immunity (Havaux et al., 2009; Goyer, 2010) (Figure 3). Previously studies show that bacteria-derived vitamins B1, B2, and $\mathrm{K} 3$, act as elicitors of plant immunity against pathogenic fungi, bacteria, and viruses, and that biotin, thiamine, cobalamin, pantothenic acid, and niacin produced by bacteria enhance plant growth (Strzelczyk et al., 1991; Ahn et al., 2005; Taheri and Hofte, 2007; Liu et al., 2010; Taheri and Tarighi, 2010; Song et al., 2013). Cyanobacteria such as Spirulina, Anabaena, Microcystis, Nostoc, Phormidium, Oscillatoria, Chroococcus, and eukaryotic algae such as Euglrena, also produce thiamine (vitamin B1), riboflavin (vitamin B2), folic acid, ascorbic acid, nicotinic acid (vitamin B3), cyanocobalamin (vitamin B12), and vitamin E (Robbins et al., 1951; Koptera, 1970; Aaronson et al., 1977; Shah and Vaidya, 1977; Gupta et al., 2013). In addition, the extract of N. muscorum and Hapalosiphon containing vitamin B-complex (including cyanocobalamin, niacin, pantothenic acid, and folic acid) increases coleoptile length and leaf length in rice (Misra and Kaushik, 1989). Since land plants lack vitamin B12, their growth is supported by beneficial microbes containing vitamin B12 (Watanabe and Bito, 2018). Similarly, as beneficial microbes, microalgal species can also alleviate vitamin B deficiency in host plants. Further investigation of the effects of algae-derived macro- and micronutrients in plants is needed.

\section{INTERACTION BETWEEN MICROALGAE AND OTHER MICROBES IN THE PLANT MICROBIOME}

Algae benefit plants through several mechanisms. In order to consider microalgae as part of the plant microbiome, it is necessary to understand the interactions between microalgae and other plant microbiota. Interestingly, previous reports showed the synergism between algae and bacteria during co-inoculation of plants. A mixture of cyanobacteria and plant-associated eubacteria or fungi additively or synergistically improves the growth and health of diverse crop plants (Tables 1, 3) (Nain et al., 2010; Dukare et al., 2011; Rana et al., 2015; Sharma et al., 2020).
Soil inoculation with a mixture containing the cyanobacterium Anabaena oscillarioides and plant growth-promoting bacteria Brevundimonas diminuta and Ochrobactrum anthropi improved rice yield by 1.2-fold compared with the control (Rana et al., 2015). Treatment with a biofilm comprising $A$. torulosa and the plant growth-promoting fungus Trichoderma viride increased the seed germination rate and radicle length in maize (Sharma et al., 2020). In addition, the combined application of Anabaena spp. and $B$. subtilis reduced the severity of fungal disease caused by Fusarium, Pythium, and Rhizoctonia by twofold compared with the control (Dukare et al., 2011).

The interaction between microalgae and other microorganisms might be governed by interspecific exchange of metabolites (Gonzalez and Bashan, 2000; Kazamia et al., 2012; Kim et al., 2014). Plant-associated rhizobacteria or fungi support the growth and root colonization of microalgae species by providing secondary metabolites such as vitamin B12, siderophores, volatile compounds, $\mathrm{N}$-acylhomoserine lactone, and EPSs (Gobler et al., 2007; Choix et al., 2012; Kazamia et al., 2012; Santos and Reis, 2014; Amavizca et al., 2017; Cho et al., 2019; Sharma et al., 2020). In turn, microalgae provide photosynthates, including fixed carbon, as nutrient sources for soil-borne microbes (Gobler et al., 2007; Kazamia et al., 2012). Taken together, these studies imply that exogenous microalgae can interact with other soil-borne microbes in plant microbiome, as do traditional plant-associated bacteria and fungi.

\section{RHIZOSPHERE MICROBIOME ENGINEERING WITH ALGAE}

Modification of the rhizosphere using microalgae, including cyanobacteria and eukaryotic microalgae, will potentially allow us to engineer and change the structure and effectiveness of the rhizosphere microbiome, thereby improving plant health. Previously, the effect of soil algae diversity on plants was investigated by application of a commercial proprietary suspension of microalgae called GOgreen ${ }^{\circledR}$ (Hastings et al., 2014). Four algal groups, including green algae (Chlorophyta), bluegreen algae (Cyanophyta), yellow-green algae (Xanthophyta), and diatoms (Bacillariophyta), are mainly found in soil (Paul and Clark, 1989). The application of GOgreen ${ }^{\circledR}$ to maize roots under field conditions increased the number and diversity of diatoms and reduced the soil $\mathrm{pH}$ with a $\mathrm{pH}$ higher than 7. Since the connection between species diversity and their influence on ecological function is unclear, the authors measured two indicators of soil quality: organic matter content (OM) and cation exchange capacity (CEC). The values of OM and CEC were improved significantly by algae treatment (Hastings et al., 2014). In addition, inoculation of rice plants with the cyanobacterium Calothrix elenkenii increased the bacterial population diversity in the microbiome by 10-fold (Priya et al., 2015). Fatty acid methyl ester analysis and 16S rRNA sequencing data indicated that Bacillaceae was the most abundant bacterial group induced by cyanobacteria inoculation. Moreover, C. elenkenii inoculation increased the shoot length, root length, fresh weight, and dry weight of plants as well as enhanced the level of plant hormones 
(IAA and $\mathrm{ABA}$ ), chlorophyll, and antioxidant enzymes (POD, polyphenol oxidase [PPO], and PAL). However, direct evidence based on experiments using the gnotobiotic system was not provided. In the line of this study, more direct approaches were also attempted. Next-generation sequencing of $16 \mathrm{~S}$ rRNA amplicons was conducted to determine the effect of $C$. vulgaris application on bean root microbiota (Kublanovskaya et al., 2019). Interestingly, no significant changes were detected in bacterial diversity in the bean rhizosphere upon the application of C. vulgaris. Algae-mediated microbiome engineering for promoting plant health is in its infancy. Fine-tuning microbiome engineering for keystone taxa that affect plant growth and health is necessary, and algae and their products can be utilized for this purpose.

A synthetic microbiome comprising algae and bacteria represents a promising tool for the sustainable development of soil fertility, water preservation, and plant growth, especially under stress conditions (Nain et al., 2010; Rana et al., 2015; Perea et al., 2018). A consortium of eukaryotic microalgae, cyanobacteria, and bacteria will provide organic carbon for plant growth (Belnap, 2003; Bashan and de-Bashan, 2010), fix atmospheric nitrogen (Issa et al., 2001; Pointing and Belnap, 2012), and promote seedling survival (Godínez-Alvarez et al., 2012). Detailed investigation of the algae-bacteria network and their effect on the plant microbiome is required to maximize plant growth and protect plants against pathogens (Krug et al., 2020).

\section{POTENTIAL APPLICATIONS OF ALGAE}

The beneficial effects of algae on plants and agriculture have been described above. Large-scale production of algae has been optimized for improving human health; however, the application of algae for large-scale crop cultivation has not been elucidated. We summarized the determinants of algae that augment plant growth and immunity, and classified these determinants as secreted products and the cell itself (Figure 2). The inoculation of plants with cell wall components such as glucans, increased plant growth and activated plant defense responses (Mercier et al., 2001; Sangha et al., 2010, 2015; Vera et al., 2012; Ghannam et al., 2013; Shukla et al., 2016; Pettongkhao et al., 2019; Zou et al., 2019, Figure 3). The products secreted by algae can be harvested in large amounts when algae are grown in liquid media. D-lactic acid was recently identified as an algal determinant that elicits plant immune response against bacterial pathogens (Lee et al., 2020a, Figure 3). Additionally, plant defense hormone-mimicking compounds, such as JA, benzoic acid and ET, were also detected in algae culture (Rodgers et al., 1979; Kreslavsky et al., 1997; Tsavkelova et al., 2006; Natarajan et al., 2012, Figure 3). These defense hormones strongly activate plant defense when supplied exogenously. Cell and cell envelope components of algae can be used for limited applications in the greenhouse and field to reduce the high production cost, although these products demonstrate high efficacy (Choleva et al., 2005, 2007; Dubey and Dubey, 2010; Bileva, 2013; Coppens et al., 2016). Products secreted in the liquid culture of algae also show a great potential for application in the field (Shaaban, 2001a,b; Barone et al., 2018; Mutale-joan et al., 2020). Generally, largescale production of algae, mostly by heterotrophic cultivation, is performed to harvest algal cells (Lee et al., 2020a). The cellfree components are considered waste products that need to be detoxified. If the cell-free extracts can be reused for plants, their potential applications will increase greatly.

However, several issues must be addressed prior to application of algae on crop plants. First, the potential harmful effects of cell-free extracts of algae should be evaluated and eliminated. In many cases, algae produce toxic compounds during cultivation. For instance, at high concentrations, 2,4-D (auxin) acts as a herbicide (Marth and Mitchell, 1944). Thus, quality control of the liquid culture of algae is critical. Second, production of algal determinants should be optimized for large-scale production. Third, formulation of cell-free extracts should be carefully considered. The cell-free extract could simply be applied by drench application or by using the drip-irrigation system. However, the delivery of a large volume of extract is problematic. Therefore, the extract should be vaporized and purified using chemical and physical procedures, and the final product showing high effectiveness should be used for agricultural applications. Furthermore, granulation of determinants is similar to that of other agricultural products such as fertilizers and agrochemicals. Finally, the specific procedure how to isolate effective algae in plant health improvement also must be developed in near future.

Previously, algae were not considered as a member of the beneficial plant microbiome. However, with recent progress in metagenome analysis, algae are now recognized as important members of the plant microbiome. While microbes such as bacteria and fungi have been used to improve plant fitness, new data indicate that algae also promote plant growth and act as biological control agents against pathogens by directly inhibiting pathogen growth and activating plant immune responses. Thus, algae represent a new bioactive material that can be utilized as biofertilizers and plant protectants, which implies that algae should be classified as a member of the beneficial plant microbiome.

\section{AUTHOR CONTRIBUTIONS}

C-MR designed the review. S-ML created the figures and tables. C-MR and S-ML wrote the manuscript. Both authors contributed to the article and approved the submitted version.

\section{FUNDING}

This research was supported by grants from the Rural Development Administration, Strategic Initiative for Microbiomes in Agriculture and Food, Ministry of Agriculture, Food and Rural Affairs, Republic of Korea (as part of the multi-ministerial Genome Technology to Business Translation Program) (918017-4), Center for Agricultural Microorganism and Enzyme (Project No. PJ015049) of Rural Development Administration, and the KRIBB Initiative Program, South Korea. 


\section{REFERENCES}

Aaronson, S., Dhawale, S., Patni, N., DeAngelis, B., Frank, O., and Baker, H. (1977). The cell content and secretion of water-soluble vitamins by several freshwater algae. Arch. Microbiol. 112, 57-59. doi: 10.1007/bf004 46654

Abd El-Baky, H. H., El-Baz, F. K., and El Baroty, G. S. (2010). Enhancing antioxidant availability in wheat grains from plants grown under seawater stress in response to microalgae extract treatments. J. Sci. Food Agricult. 90, 299-303. doi: $10.1002 /$ jsfa. 3815

Adesalu, T., and Olugbemi, O. (2015). Soil algae: a case study of two vegetable farmlands in Lagos and Ogun states, southwest Nigeria. IFE J. Sci. 17, 765-772.

Ahmed, M., Stal, L. J., and Hasnain, S. (2010). Association of non-heterocystous cyanobacteria with crop plants. Plant Soil 336, 363-375. doi: 10.1007/s11104010-0488-x

Ahn, I.-P., Kim, S., and Lee, Y.-H. (2005). Vitamin B1 functions as an activator of plant disease resistance. Plant Physiol. 138, 1505-1515. doi: 10.1104/pp.104. 058693

Ali, S., Charles, T., and Glick, B. (2012). Delay of flower senescence by bacterial endophytes expressing 1-aminocyclopropane-1-carboxylate deaminase. J. Appl. Microbiol. 113, 1139-1144. doi: 10.1111/j.1365-2672.2012.05409.x

Amavizca, E., Bashan, Y., Ryu, C. M., Farag, M. A., Bebout, B. M., and de-Bashan, L. E. (2017). Enhanced performance of the microalga Chlorella sorokiniana remotely induced by the plant growth-promoting bacteria Azospirillum brasilense and Bacillus pumilus. Sci. Rep. 7, 1-11.

An, B., Lan, J., Deng, X., Chen, S., Ouyang, C., Shi, H., et al. (2017). Silencing of D-lactate dehydrogenase impedes glyoxalase system and leads to methylglyoxal accumulation and growth inhibition in rice. Front. Plant Sci. 8:2071. doi: 10. 3389/fpls.2017.02071

Arroussi, H. E., Benhima, R., Elbaouchi, A., Sijilmassi, B., Mernissi, N. E., Aafsar, A., et al. (2018). Dunaliella salina exopolysaccharides: a promising biostimulant for salt stress tolerance in tomato (Solanum lycopersicum). J. Appl. Phycol. 30, 2929-2941. doi: 10.1007/s10811-017-1382-1

Atlante, A., de Bari, L., Valenti, D., Pizzuto, R., Paventi, G., and Passarella, S. (2005). Transport and metabolism of D-lactate in Jerusalem artichoke mitochondria. Biochim. Biophys. Acta Bioenerg. 1708, 13-22. doi: 10.1016/j.bbabio.2005.03.003

Babu, S., Prasanna, R., Bidyarani, N., and Singh, R. (2015). Analysing the colonisation of inoculated cyanobacteria in wheat plants using biochemical and molecular tools. J. Appl. Phycol. 27, 327-338. doi: 10.1007/s10811-014-0322-6

Barone, V., Baglieri, A., Stevanato, P., Broccanello, C., Bertoldo, G., Bertaggia, M., et al. (2018). Root morphological and molecular responses induced by microalgae extracts in sugar beet (Beta vulgaris L.). J. Appl. Phycol. 30, 10611071. doi: 10.1007/s10811-017-1283-3

Barone, V., Puglisi, I., Fragalà, F., Piero, A. R. L., Giuffrida, F., and Baglieri, A. (2019). Novel bioprocess for the cultivation of microalgae in hydroponic growing system of tomato plants. J. Appl. Phycol. 31, 465-470. doi: 10.1007/ s10811-018-1518-y

Bashan, Y., and de-Bashan, L. E. (2010). "Microbial populations of arid lands and their potential for restoration of deserts," in Soil biology and agriculture in the tropics, ed. P. Dion (Berlin: Springer), 109-137. doi: 10.1007/978-3-642-050763_6

Belnap, J. (2003). The world at your feet: desert biological soil crusts. Front. Ecol. Environ. 1, 181-189. doi: 10.2307/3868062

Benderliev, K. (1999). Algae and cyanobacteria release organic chelators in the presence of inorganic Fe (III) thus keeping iron dissolved. Bulg. J. Plant Physiol. $25,65-75$.

Benderliev, K., Ivanova, N., and Pilarski, P. (2003). Singlet oxygen and other reactive oxygen species are involved in regulation of release of iron-binding chelators from Scenedesmus cells. Biologia Plant. 47, 523-526. doi: 10.1023/b: biop.0000041056.07819.df

Benjamins, R., and Scheres, B. (2008). Auxin: the looping star in plant development. Annu. Rev. Plant Biol. 59, 443-465. doi: 10.1146/annurev.arplant. 58.032806.103805

Bérard, A., Dorigo, U., Humbert, J. F., and Martin-Laurent, F. (2005). Microalgae community structure analysis based on $18 \mathrm{~S}$ rDNA amplification from DNA extracted directly from soil as a potential soil bioindicator. Agronomy Sustainable Dev. 25, 285-291. doi: 10.1051/agro:2005004
Berg, G., Rybakova, D., Fischer, D., Cernava, T., Vergès, M.-C. C., Charles, T., et al. (2020). Microbiome definition re-visited: old concepts and new challenges. Microbiome 8, 1-22.

Bergman, B., Johansson, C., and Soderback, E. (1992). Tansley Review No. 42. The Nostoc-Gunnera symbiosis. N. Phytol. 122, 379-400. doi: 10.1111/j.1469-8137. 1992.tb00067.x

Bhowal, B., Singla-Pareek, S. L., Sopory, S. K., and Kaur, C. (2020). From methylglyoxal to pyruvate: a genome-wide study for the identification of glyoxalases and D-lactate dehydrogenases in Sorghum bicolor. BMC Genomics 21:145. doi: 10.1186/s12864-020-6547-7

Bidyarani, N., Prasanna, R., Chawla, G., Babu, S., and Singh, R. (2015). Deciphering the factors associated with the colonization of rice plants by cyanobacteria. J. Basic Microbiol. 55, 407-419. doi: 10.1002/jobm.201400591

Bileva, T. (2013). Influence of green algae Chlorella vulgaris on infested with xiphinema index grape seedlings. J. Earth Sci. Clim. Change 4, 136-138.

Biondi, N., Piccardi, R., Margheri, M. C., Rodolfi, L., Smith, G. D., and Tredici, M. R. (2004). Evaluation of Nostoc strain ATCC 53789 as a potential source of natural pesticides. Appl. Environ. Microbiol. 70, 3313-3320. doi: 10.1128/aem. 70.6.3313-3320.2004

Blaby-Haas, C. E., and Merchant, S. S. (2019). Comparative and functional algal genomics. Annu. Rev. Plant Biol. 70, 605-638.

Bradley, I. M., Pinto, A. J., and Guest, J. S. (2016). Design and evaluation of Illumina MiSeq-compatible, 18S rRNA gene-specific primers for improved characterization of mixed phototrophic communities. Appl. Environ. Microbiol. 82, 5878-5891. doi: 10.1128/aem.01630- 16

Braun-Howland, E. B., and Nierzwicki-Bauer, S. A. (1990). Azolla-Anabaena symbiosis: biochemistry, physiology, ultrastructure, and molecular biology. Boca Raton: CRC Press.

Bumandalai, O., and Tserennadmid, R. (2019). Effect of Chlorella vulgaris as a biofertilizer on germination of tomato and cucumber seeds. Int. J. Aquat. Biol. 7, 95-99.

Carlson, A. S., Dole, J. M., Matthysse, A. G., Hoffmann, W. A., and Kornegay, J. L. (2015). Bacteria species and solution $\mathrm{pH}$ effect postharvest quality of cut Zinnia elegans. Sci. Horticult. 194, 71-78. doi: 10.1016/j.scienta.2015.07.044

Carmichael, W. W. (1994). The toxin of cyanobacteria. Sci. Am. 270, 64-70.

Chaudhary, V., Prasanna, R., Nain, L., Dubey, S., Gupta, V., Singh, R., et al. (2012). Bioefficacy of novel cyanobacteria-amended formulations in suppressing damping off disease in tomato seedlings. World J. Microbiol. Biotechnol. 28, 3301-3310. doi: 10.1007/s11274-012-1141-z

Cheng, C. Y., Mathews, D. E., Eric Schaller, G., and Kieber, J. J. (2013). Cytokinindependent specification of the functional megaspore in the Arabidopsis female gametophyte. Plant J. 73, 929-940. doi: 10.1111/tpj.12084

Cho, K., Heo, J., Cho, D. H., Tran, Q. G., Yun, J. H., Lee, S. M., et al. (2019). Enhancing algal biomass and lipid production by phycospheric bacterial volatiles and possible growth enhancing factor. Algal Res. 37, 186-194. doi: 10.1016/j.algal.2018.11.011

Choix, F. J., de-Bashan, L. E., and Bashan, Y. (2012). Enhanced accumulation of starch and total carbohydrates in alginate-immobilized Chlorella spp. induced by Azospirillum brasilense: II. Heterotrophic conditions. Enzyme Microb. Technol. 51, 300-309. doi: 10.1016/j.enzmictec.2012.07.012

Choleva, B., Bileva, T., and Tsvetkov, J. (2007). Organo-biological means and methods for control of plant parasitic nematodes as alternative of agrochemicals. Ecol. Fut. 6, 43-49.

Choleva, B., Bileva, T., Tzvetkov, Y., and Barakov, P. (2005). Preliminary study of the green algae chlorella (Chlorella vulgaris) for control on the root-knot nematode (Meloidogyne arenaria) in tomato plants and ectoparasite Xiphinema indexin grape seedlings. Commun.Cations Agricult. Appl. Biol. Sci. 70, 915-926.

Coppens, J., Grunert, O., Van Den Hende, S., Vanhoutte, I., Boon, N., Haesaert, G., et al. (2016). The use of microalgae as a high-value organic slow-release fertilizer results in tomatoes with increased carotenoid and sugar levels. J. Appl. Phycol. 28, 2367-2377. doi: 10.1007/s10811-015-0775-2

Cuddy, W. S., Neilan, B. A., and Gehringer, M. M. (2012). Comparative analysis of cyanobacteria in the rhizosphere and as endosymbionts of cycads in droughtaffected soils. FEMS Microbiol. Ecol. 80, 204-215. doi: 10.1111/j.1574-6941. 2011.01288.x

Davey, M. C. (1989). The effects of freezing and desiccation on photosynthesis and survival of terrestrial Antarctic algae and cyanobacteria. Polar Biol. 10, 29-36. 
Davey, M. C. (1991). The seasonal periodicity of algae on Antarctic fellfield soils. Ecography 14, 112-120. doi: 10.1111/j.1600-0587.1991.tb00641.x

Davey, M., and Clarke, K. (1991). The spatial distribution of microalgae on Antarctic fellfield soils. Antarctic Sci. 3, 257-263. doi: 10.1017/ s0954102091000317

De Meyer, G., Capieau, K., Audenaert, K., Buchala, A., Métraux, J.-P., and Höfte, M. (1999). Nanogram amounts of salicylic acid produced by the rhizobacterium Pseudomonas aeruginosa 7NSK2 activate the systemic acquired resistance pathway in bean. Mol. Plant Microbe Interact. 12, 450-458. doi: 10.1094/mpmi. 1999.12.5.450

Dessaux, Y., Grandclément, C., and Faure, D. (2016). Engineering the rhizosphere. Trends Plant Sci. 21, 266-278.

Dimitrov, P., and Zucker, S. W. (2006). A constant production hypothesis guides leaf venation patterning. Proc. Natl. Acad. Sci. 103, 9363-9368. doi: 10.1073/ pnas. 0603559103

Dow, C. S., and Swoboda, U. K. (2000). Cyanotoxins. In The ecology of Cyanobacteria. Berlin: Springer, 613-632.

Dubey, A., and Dubey, D. (2010). Evaluation of cost effective organic fertilizers. India: Kilpest India Ltd.

Duijff, B. J., Meijer, J. W., Bakker, P. A., and Schippers, B. (1993). Siderophoremediated competition for iron and induced resistance in the suppression of Fusarium wilt of carnation by fluorescent Pseudomonas spp. Netherl. J. Plant Pathol. 99, 277-289. doi: 10.1007/bf01974309

Dukare, A. S., Prasanna, R., Dubey, S. C., Nain, L., Chaudhary, V., Singh, R., et al. (2011). Evaluating novel microbe amended composts as biocontrol agents in tomato. Crop Protect. 30, 436-442. doi: 10.1016/j.cropro.2010.12.017

Elarroussia, H., Elmernissia, N., Benhimaa, R., El Kadmiria, I. M., Bendaou, N., Smouni, A., et al. (2016). Microalgae polysaccharides a promising plant growth biostimulant. J. Algal Biomass Utilizat. 7, 55-63.

Elster, J. (2002). "Ecological classification of terrestrial algal communities in polar environments," in Geoecology of Antarctic ice-free coastal landscapes, eds L. Beyer and M. Bölter (Berlin: Springer), 303-326. doi: 10.1007/978-3-64256318-8_17

Erbs, G., and Newman, M. A. (2003). The role of lipopolysaccharides in induction of plant defence responses. Mol. Plant Pathol. 4, 421-425. doi: 10.1046/j.13643703.2003.00179.x

Faheed, F. A., and Fattah, Z. A. (2008). Effect of Chlorella vulgaris as bio-fertilizer on growth parameters and metabolic aspects of lettuce plant. J. Agricult. Soc. Sci. 4, 165-169.

Farid, R., Mutale-joan, C., Redouane, B., Najib, E. M., Abderahime, A., Laila, S., et al. (2019). Effect of microalgae polysaccharides on biochemical and metabolomics pathways related to plant defense in Solanum lycopersicum. Appl. Biochem. Biotechnol. 188, 225-240. doi: 10.1007/s12010-0182916-y

Gantar, M. (2000). Mechanical damage of roots provides enhanced colonization of the wheat endorhizosphere by the dinitrogen-fixing cyanobacterium Nostoc sp. strain 2S9B. Biol. Fertility Soils 32, 250-255. doi: 10.1007/s003740000243

Gantar, M., and Elhai, J. (1999). Colonization of wheat para-nodules by the N 2fixing cyanobacterium Nostoc sp. strain 2S9B. N. Phytol. 141, 373-379. doi: 10.1046/j.1469-8137.1999.00352.x

Gantar, M., Kerby, N., and Rowell, P. (1991). Colonization of wheat (Triticum vulgare L.) by N2-fixing cyanobacteria: II. An ultrastructural study. N. Phytol. 118, 485-492. doi: 10.1111/j.1469-8137.1991.tb00031.x

Gantar, M., Kerby, N., and Rowell, P. (1993). Colonization of wheat (Triticum vulgare L.) by N2-fixing cyanobacteria: III. The role of a hormogoniapromoting factor. N. Phytol. 124, 505-513. doi: 10.1111/j.1469-8137.1993. tb03842.x

Gantar, M., Rowell, P., Kerby, N. W., and Sutherland, I. W. (1995). Role of extracellular polysaccharide in the colonization of wheat (Triticum vulgare L.) roots by N 2-fixing cyanobacteria. Biol. Fertility Soils 19, 41-48. doi: 10.1007/ bf 00336345

Ghannam, A., Abbas, A., Alek, H., Al-Waari, Z., and Al-Ktaifani, M. (2013). Enhancement of local plant immunity against tobacco mosaic virus infection after treatment with sulphated-carrageenan from red alga (Hypnea musciformis). Physiol. Mol. Plant Pathol. 84, 19-27. doi: 10.1016/j.pmpp.2013. 07.001

Gobler, C. J., Norman, C., Panzeca, C., Taylor, G. T., and Sañudo-Wilhelmy, S. A. (2007). Effect of B-vitamins (B1, B12) and inorganic nutrients on algal bloom dynamics in a coastal ecosystem. Aquat. Microb. Ecol. 49, 181-194. doi: 10.3354/ame01132

Godínez-Alvarez, H., Morín, C., and Rivera-Aguilar, V. (2012). Germination, survival and growth of three vascular plants on biological soil crusts from a Mexican tropical desert. Plant Biol. 14, 157-162.

Goldman, S., Lammers, P., Berman, M., and Sanders-Loehr, J. (1983). Siderophoremediated iron uptake in different strains of Anabaena sp. J. Bacteriol. 156, 1144-1150. doi: 10.1128/jb.156.3.1144-1150.1983

Gonzalez, L. E., and Bashan, Y. (2000). Increased growth of the microalga chlorella vulgariswhen coimmobilized and cocultured in alginate beads with the plant-growth-promoting bacterium Azospirillum brasilense. Appl. Environ. Microbiol. 66, 1527-1531. doi: 10.1128/aem.66.4.1527-1531.2000

Goyer, A. (2010). Thiamine in plants: aspects of its metabolism and functions. Phytochemistry 71, 1615-1624. doi: 10.1016/j.phytochem.2010.06.022

Gruber, P. J., Frederick, S. E., and Tolbert, N. (1974). Enzymes related to lactate metabolism in green algae and lower land plants. Plant Physiol. 53, 167-170. doi: $10.1104 /$ pp.53.2.167

Gupta, V., Ratha, S. K., Sood, A., Chaudhary, V., and Prasanna, R. (2013). New insights into the biodiversity and applications of cyanobacteria (blue-green algae)—prospects and challenges. Algal Res. 2, 79-97. doi: 10.1016/j.algal.2013. 01.006

Hamann, T., Benkova, E., Bäurle, I., Kientz, M., and Jürgens, G. (2002). The Arabidopsis BODENLOS gene encodes an auxin response protein inhibiting MONOPTEROS-mediated embryo patterning. Genes Dev. 16, 1610-1615. doi: 10.1101/gad.229402

Hamouda, R. A., and El-Ansary, M. (2013). Biocontrol of Root knot Nematode, Meloidogyne incognita infected banana plants by Cyanobacteria. Egypt. J. Agronematol. 12, 113-129.

Hamouda, R. A., and El-Ansary, M. (2017). Potential of Plant-Parasitic Nematode Control in Banana Plants by Microalgae as a New Approach Towards Resistance. Egypt. J. Biol. Pest Control 27, 165-172.

Hashtroudi, M. S., Ghassempour, A., Riahi, H., Shariatmadari, Z., and Khanjir, M. (2013). Endogenous auxins in plant growth-promoting CyanobacteriaAnabaena vaginicola and Nostoc calcicola. J. Appl. Phycol. 25, 379-386. doi: 10.1007/s10811-012-9872-7

Hastings, K. L., Smith, L. E., Lindsey, M. L., Blotsky, L. C., Downing, G. R., et al. (2014). Effect of microalgae application on soil algal species diversity, cation exchange capacity and organic matter after herbicide treatments. F1000Research 3:281. doi: 10.12688/f1000research.4016.1

Havaux, M., Ksas, B., Szewczyk, A., Rumeau, D., Franck, F., et al. (2009). Vitamin B6 deficient plants display increased sensitivity to high light and photooxidative stress. BMC Plant Biol. 9:130. doi: 10.1186/1471-2229-9-130

Holajjer, P., Kamra, A., Gaur, H., and Manjunath, M. (2013). Potential of cyanobacteria for biorational management of plant parasitic nematodes: a review. Crop Protect. 53, 147-151. doi: 10.1016/j.cropro.2013.07.005

Husic, D. W., and Tolbert, N. (1987). Inhibition of glycolate and D-lactate metabolism in a Chlamydomonas reinhardtii mutant deficient in mitochondrial respiration. Proc. Natl. Acad. Sci. 84, 1555-1559. doi: 10.1073/pnas.84.6.1555

Hussain, A., and Hasnain, S. (2011). Phytostimulation and biofertilization in wheat by cyanobacteria. J. Industr. Microbiol. Biotechnol. 38, 85-92. doi: 10.1007/ s10295-010-0833-3

Hussain, A., Hamayun, M., and Shah, S. T. (2013). Root colonization and phytostimulation by phytohormones producing entophytic Nostoc sp. AH-12. Curr. Microbiol. 67, 624-630. doi: 10.1007/s00284-013-0408-4

Hussain, A., Krischke, M., Roitsch, T., and Hasnain, S. (2010). Rapid determination of cytokinins and auxin in cyanobacteria. Curr. Microbiol. 61, 361-369. doi: 10.1007/s00284-010-9620-7

Hussain, A., Shah, S. T., Rahman, H., Irshad, M., and Iqbal, A. (2015). Effect of IAA on in vitro growth and colonization of Nostoc in plant roots. Front. Plant Sci. 6:46. doi: $10.3389 /$ fpls.2015.00046

Innok, S., Chunleuchanon, S., Boonkerd, N., and Teaumroong, N. (2009). Cyanobacterial akinete induction and its application as biofertilizer for rice cultivation. J. Appl. Phycol. 21:737. doi: 10.1007/s10811-009-9409-x

Issa, O. M., Stal, L. J., Défarge, C., Couté, A., and Trichet, J. (2001). Nitrogen fixation by microbial crusts from desiccated Sahelian soils (Niger). Soil Biol. Biochem. 33, 1425-1428. doi: 10.1016/s0038-0717(01)00046-3

Jain, M., Aggarwal, S., Nagar, P., Tiwari, R., and Mustafiz, A. (2020). A D-lactate dehydrogenase from rice is involved in conferring tolerance to 
multiple abiotic stresses by maintaining cellular homeostasis. Sci. Rep. 10, $1-17$.

Jain, M., Nagar, P., Sharma, A., Batth, R., Aggarwal, S., Kumari, S., et al. (2018). GLYI and D-LDH play key role in methylglyoxal detoxification and abiotic stress tolerance. Sci. Rep. 8, 1-9.

Jaki, B., Orjala, J., Heilmann, J., Linden, A., Vogler, B., and Sticher, O. (2000). Novel Extracellular Diterpenoids with Biological Activity from the Cyanobacterium Nostoc c ommune. J. Nat. Products 63, 339-343. doi: 10.1021/np9903090

Karthikeyan, N., Prasanna, R., Nain, L., and Kaushik, B. D. (2007). Evaluating the potential of plant growth promoting cyanobacteria as inoculants for wheat. Eur. J. Soil Biol. 43, 23-30. doi: 10.1016/j.ejsobi.2006.11.001

Karthikeyan, N., Prasanna, R., Sood, A., Jaiswal, P., Nayak, S., and Kaushik, B. (2009). Physiological characterization and electron microscopic investigation of cyanobacteria associated with wheat rhizosphere. Folia Microbiol. 54, 43-51. doi: 10.1007/s12223-009-0007-8

Kazamia, E., Czesnick, H., Nguyen, T. T. V., Croft, M. T., Sherwood, E., et al. (2012). Mutualistic interactions between vitamin B12-dependent algae and heterotrophic bacteria exhibit regulation. Environ. Microbiol. 14, 1466-1476. doi: 10.1111/j.1462-2920.2012.02733.x

Khan, Z., Kim, Y., Kim, S., and Kim, H. (2007). Observations on the suppression of root-knot nematode (Meloidogyne arenaria) on tomato by incorporation of cyanobacterial powder (Oscillatoria chlorina) into potting field soil. Bioresour. Technol. 98, 69-73. doi: 10.1016/j.biortech.2005.11.029

Khan, Z., Park, S., Shin, S., Bae, S., Yeon, I., and Seo, Y. (2005). Management of Meloidogyne incognita on tomato by root-dip treatment in culture filtrate of the blue-green alga, Microcoleus vaginatus. Bioresour. Technol. 96, 1338-1341.

Khaw, Y. S., Khong, N. M., Shaharuddin, N. A., and Yusoff, F. M. (2020). A simple $18 \mathrm{~S}$ rDNA approach for the identification of cultured eukaryotic microalgae with an emphasis on primers. J. Microbiol. Methods 172:105890.

Kim, J., and Kim, J.-D. (2008). Inhibitory effect of algal extracts on mycelial growth of the tomato-wilt pathogen, Fusarium oxysporum f. sp. lycopersici. Mycobiology 36, 242-248.

Kim, M., Shim, C., Kim, Y., Park, J., Hong, S., Ji, H., et al. (2014). Effect of Chlorella vulgaris CHK0008 fertilization on enhancement of storage and freshness in organic strawberry and leaf vegetables. Kor. J. Horticult. Sci. Technol. 32, $872-878$.

Kim, M.-J., Shim, C.-K., Kim, Y.-K., Jee, H.-J., Park, J.-H., Hong, S.-J., et al. (2012). Effect of Green Algae, Chlorella fusca on Improving Seed Germination and Seedling Growth in Vegetable Crop and Minor Cereal. Kor. J. Org. Agric. 2012, 491-492.

Kim, M.-J., Shim, C.-K., Kim, Y.-K., Ko, B.-G., Park, J.-H., Hwang, S.-G., et al. (2018a). Effect of biostimulator Chlorella fusca on improving growth and qualities of chinese chives and spinach in organic farm. Plant Pathol. J. 34:567.

Kim, S. J., Ko, E. J., Hong, J. K., and Jeun, Y. C. (2018b). Ultrastructures of Colletotrichum orbiculare in cucumber leaves expressing systemic acquired resistance mediated by Chlorella fusca. Plant Pathol. J. 34:113.

Kloepper, J. W., Leong, J., Teintze, M., and Schroth, M. N. (1980). Enhanced plant growth by siderophores produced by plant growth-promoting rhizobacteria. Nature 286, 885-886.

Kloepper, J. W., Ryu, C.-M., and Zhang, S. (2004). Induced systemic resistance and promotion of plant growth by Bacillus spp. Phytopathology 94, 1259-1266.

Konst, H., McKercher, P., Gorham, P., Robertson, A., and Howell, J. (1965). Symptoms and pathology produced by toxic Microcystis aeruginosa NRC-1 in laboratory and domestic animals. Can. J. Comparat. Med. Vet. Sci. 29:221.

Koptera, Z. (1970). Biosynthesis of biotin, pyredoxin, nicotinic acid and pantothenic acids by some blue-green algae. Microbiol. Z 32, 555-560.

Kreslavsky, V., Kobzar, E., and Muzafarov, E. (1997). Effect of red radiation, kinetin and linuron on growth and ethylene production in Chlorella. Biol. Plant. 39, 427-430.

Krings, M., Hass, H., Kerp, H., Taylor, T. N., Agerer, R., and Dotzler, N. (2009). Endophytic cyanobacteria in a 400-million-yr-old land plant: A scenario for the origin of a symbiosis? Rev. Palaeobot. Palynol. 153, 62-69.

Krug, L., Erlacher, A., Markut, K., Berg, G., and Cernava, T. (2020). The microbiome of alpine snow algae shows a specific inter-kingdom connectivity and algae-bacteria interactions with supportive capacities. ISME J. 14, $2197-$ 2210 .

Kuan, K. B., Othman, R., Abdul Rahim, K., and Shamsuddin, Z. H. (2016). Plant growth-promoting rhizobacteria inoculation to enhance vegetative growth, nitrogen fixation and nitrogen remobilisation of maize under greenhouse conditions. PLoS One 11:e0152478. doi: 10.1371/journal.pone.0152478

Kublanovskaya, A., Khapchaeva, S., Zotov, V., Zaytsev, P., Lobakova, E., and Solovchenko, A. (2019). The Effect of the Microalga Chlorella vulgaris Ippas C-1 Biomass Application on Yield, Biological Activity, and the Microbiome of the Soil during Bean Growing. Moscow Univ. Biol. Sci. Bull. 74, 227-234.

Kumar, M., Prasanna, R., Bidyarani, N., Babu, S., Mishra, B. K., Kumar, A., et al. (2013). Evaluating the plant growth promoting ability of thermotolerant bacteria and cyanobacteria and their interactions with seed spice crops. Sci. Horticult. 164, 94-101.

Leach, J. E., Triplett, L. R., Argueso, C. T., and Trivedi, P. (2017). Communication in the phytobiome. Cell 169, 587-596. doi: 10.1016/j.cell.2017.04.025

Lee, S. M., Kim, S. K., Lee, N., Ahn, C. Y., and Ryu, C. M. (2020a). D-Lactic acid secreted by Chlorella fusca primes pattern-triggered immunity against Pseudomonas syringae in Arabidopsis. Plant J. 102, 761-778. doi: 10.1111/tpj. 14661

Lee, S. M., Lee, B., Shim, C. K., Chang, Y. K., and Ryu, C. M. (2020b). Plant anti-aging: Delayed flower and leaf senescence in Erinus alpinus treated with cell-free Chlorella cultivation medium. Plant Signal. Behav. 15:1763005. doi: 10.1080/15592324.2020.1763005

Lee, Y. J., Kim, S. J., and Jeun, Y. C. (2017). Ultra-structural Observations of Colletotrichum orbiculare on Cucumber Leaves Pre-treated with Chlorella fusca. Res. Plant Dis. 23, 42-48. doi: 10.5423/RPD.2017.23. 1.42

Lee, Y. J., Ko, Y. J., and Jeun, Y. C. (2016). Illustration of disease suppression of anthracnose on cucumber leaves by treatment with Chlorella fusca. Res. Plant Dis. 22, 257-263. doi: 10.5423/RPD.2016.22.4.257

Lemanceau, P., and Alabouvette, C. (1993). Suppression of Fusarium wilts by fluorescent pseudomonads: mechanisms and applications. Biocontr. Sci. Technol. 3, 219-234. doi: 10.1080/09583159309355278

Li, Y., Xu, S.-S., Gao, J., Pan, S., and Wang, G.-X. (2014). Chlorella induces stomatal closure via NADPH oxidase-dependent ROS production and its effects on instantaneous water use efficiency in Vicia faba. PLoS One 9:e93290. doi: 10.1371/journal.pone.0093290

Lim, P. O., Kim, H. J., and Gil Nam, H. (2007). Leaf senescence. Annu. Rev. Plant Biol. 58, 115-136. doi: 10.1146/annurev.arplant.57.032905.105316

Lindblad, P., Bergman, B., and Rai, A. N. (1990). "The cycad-cyanobacterial symbiosis," in CRC handbook of symbiotic cyanobacteria, ed. A. N. Rai (Florida: CRC Press), 137-159. doi: 10.1201/9781351071185-6

Liu, F., Wei, F., Wang, L., Liu, H., Zhu, X., and Liang, Y. (2010). Riboflavin activates defense responses in tobacco and induces resistance against Phytophthora parasitica and Ralstonia solanacearum. Physiol. Mol. Plant Pathol. 74, 330-336. doi: 10.1016/j.pmpp.2010.05.002

Liu, J., and Chen, F. (2016). Biology and industrial applications of Chlorella: advances and prospects. Adv. Biochem. Eng. Biotechnol. 153, 1-35. doi: 10.1007/ 10_2014_286

Longford, S. R., Campbell, A. H., Nielsen, S., Case, R. J., Kjelleberg, S., and Steinberg, P. D. (2019). Interactions within the microbiome alter microbial interactions with host chemical defences and affect disease in a marine holobiont. Sci. Rep. 9, 1-13. doi: 10.1038/s41598-018-37062-z

López, A., Ming, D. S., and Towers, G. N. (2002). Antifungal Activity of Benzoic Acid Derivatives from Piper 1 anceaefolium. J. Nat. Prod. 65, 62-64. doi: 10. 1021/np010410g

Lugtenberg, B., and Kamilova, F. (2009). Plant-growth-promoting rhizobacteria. Annu. Rev. Microbiol. 63, 541-556. doi: 10.1146/annurev.micro.62.081307. 162918

Manjunath, M., Prasanna, R., Nain, L., Dureja, P., Singh, R., Kumar, A., et al. (2010). Biocontrol potential of cyanobacterial metabolites against damping off disease caused by Pythium aphanidermatum in solanaceous vegetables. Archiv. Phytopathol. Plant Protect. 43, 666-677. doi: 10.1080/03235400802075815

Mankiewicz, J., Tarczynska, M., Walter, Z., and Zalewski, M. (2003). Natural toxins from cyanobacteria. Acta Biol. Cracov. Bot. 45, 9-20.

Marsch-Martínez, N., Ramos-Cruz, D., Reyes-Olalde, J. I., Lozano-Sotomayor, P., Zúñiga-Mayo, V. M., and de Folter, S. (2012). The role of cytokinin during Arabidopsis gynoecia and fruit morphogenesis and patterning. Plant J. 72, 222-234. doi: 10.1111/j.1365-313X.2012.05062.x

Marth, P. C., and Mitchell, J. W. (1944). 2, 4-Dichlorophenoxyacetic acid as a differential herbicide. Bot. Gazette 106, 224-232. doi: 10.1086/335289 
Maurino, V. G., and Engqvist, M. K. (2015). 2-Hydroxy acids in plant metabolism. Am. Soc. Plant Biol. 13:e0182. doi: 10.1199/tab.0182

Mazur, H., Konop, A., and Synak, R. (2001). Indole-3-acetic acid in the culture medium of two axenic green microalgae. J. Appl. Phycol. 13, 35-42. doi: 10.1023/ A:1008199409953

McKnight, D. M., and Morel, F. M. (1980). Copper complexation by siderophores from filamentous blue-green algae 1. Limnol. Oceanogr. 25, 62-71. doi: 10.4319/ lo.1980.25.1.0062

Meeks, J. C., and Elhai, J. (2002). Regulation of cellular differentiation in filamentous cyanobacteria in free-living and plant-associated symbiotic growth states. Microbiol. Mol. Biol. Rev. 66, 94-121. doi: 10.1128/MMBR.66.1.94-121. 2002

Meeks, J. C., and Rai, A. (1990). "Cyanobacterial-bryophyte associations," in CRC handbook of symbiotic cyanobacteria, ed. A. N. Rai (Florida: CRC Press), 43-63. doi: 10.1201/9781351071185-3

Mendes, R., Garbeva, P., and Raaijmakers, J. M. (2013). The rhizosphere microbiome: significance of plant beneficial, plant pathogenic, and human pathogenic microorganisms. FEMS Microbiol. Rev. 37, 634-663. doi: 10.1111/ 1574-6976.12028

Mercier, L., Lafitte, C., Borderies, G., and Briand, X. (2001). Esquerré-Tugayé MT, Fournier J: The algal polysaccharide carrageenans can act as an elicitor of plant defence. N. Phytol. 149, 43-51. doi: 10.1046/j.1469-8137.2001.00011.x

Misra, S., and Kaushik, B. (1989). Growth promoting substances of cyanobacteria. I: vitamins and their influence on rice plant. Proc. Ind. Natl. Sci. Acad. Part B Biol. Sci. 55, 295-300.

Mutale-joan, C., Redouane, B., Najib, E., Yassine, K., Lyamlouli, K., Laila, S., et al. (2020). Screening of microalgae liquid extracts for their bio stimulant properties on plant growth, nutrient uptake and metabolite profile of Solanum lycopersicum L. Sci. Rep. 10, 1-12. doi: 10.1038/s41598-020-59840-4

Nain, L., Rana, A., Joshi, M., Jadhav, S. D., Kumar, D., Shivay, Y., et al. (2010). Evaluation of synergistic effects of bacterial and cyanobacterial strains as biofertilizers for wheat. Plant Soil 331, 217-230. doi: 10.1007/s11104-009-0247$\mathrm{z}$

Naing, A. H., Win, N. M., Han, J.-S., Lim, K. B., and Kim, C. K. (2017). Role of nano-silver and the bacterial strain Enterobacter cloacae in increasing vase life of cut carnation 'Omea'. Front. Plant Sci. 8:1590. doi: 10.3389/fpls.2017.01590

Natarajan, C., Prasanna, R., Gupta, V., Dureja, P., and Nain, L. (2012). Characterization of the fungicidal activity of Calothrix elenkinii using chemical methods and microscopy. Appl. Biochem. Microbiol. 48, 51-57. doi: 10.1134/ S0003683812010115

Nilsson, M., Bhattacharya, J., Rai, A., and Bergman, B. (2002). Colonization of roots of rice (Oryza sativa) by symbiotic Nostoc strains. N. Phytol. 156, 517-525. doi: $10.1046 /$ j.1469-8137.2002.00534.x

Ohta, T., Sueoka, E., Iida, N., Komori, A., Suganuma, M., Nishiwaki, R., et al. (1994). Nodularin, a potent inhibitor of protein phosphatases 1 and 2A, is a new environmental carcinogen in male F344 rat liver. Cancer Res. 54, 6402-6406.

Pagnussat, G. C., Alandete-Saez, M., Bowman, J. L., and Sundaresan, V. (2009). Auxin-dependent patterning and gamete specification in the Arabidopsis female gametophyte. Science 324, 1684-1689. doi: 10.1126/science.1167324

Park, K., Kloepper, J. W., and Ryu, C.-M. (2008). Rhizobacterial exopolysaccharides elicit induced resistance on cucumber. J. Microbiol. Biotechnol. 18, 1095-1100.

Parker, M. S., Mock, T., and Armbrust, E. V. (2008). Genomic insights into marine microalgae. Annu. Rev. Genet. 42, 619-645. doi: 10.1146/annurev.genet.42. 110807.091417

Paudel, Y., Pradhan, S., Pant, B., and Prasad, B. (2012). Role of blue green algae in rice productivity. Agricult. Biol. J. North Am. 3, 332-335. doi: 10.5251/abjna. 2012.3.8.332.335

Paul, E. A., and Clark, F. E. (1989). Soil Microbiology and Biochemistry. San Diego: Academic Press, Inc, 273. doi: 10.1016/B978-0-12-546805-3.50004-7

Perea, J. R., Llorens-Martín, M., Ávila, J., and Bolós, M. (2018). The role of microglia in the spread of tau: relevance for tauopathies. Front. Cell. Neurosci. 12:172. doi: 10.3389/fncel.2018.00172

Pettongkhao, S., Bilanglod, A., Khompatara, K., and Churngchow, N. (2019). Sulphated Polysaccharide from Acanthophora spicifera Induced Hevea brasiliensis Defense Responses Against Phytophthora palmivora Infection. Plants 8:73. doi: 10.3390/plants8030073
Pieterse, C. M., Van Wees, S. C., Van Pelt, J. A., Knoester, M., Laan, R., Gerrits, H., et al. (1998). A novel signaling pathway controlling induced systemic resistance in Arabidopsis. Plant Cell 10, 1571-1580. doi: 10.1105/tpc.10.9.1571

Pieterse, C. M., Zamioudis, C., Berendsen, R. L., Weller, D. M., Van Wees, S. C., and Bakker, P. A. (2014). Induced systemic resistance by beneficial microbes. Annu. Rev. Phytopathol. 52, 347-375. doi: 10.1146/annurev-phyto-082712-102340

Pointing, S. B., and Belnap, J. (2012). Microbial colonization and controls in dryland systems. Nat. Rev. Microbiol. 10, 551-562. doi: 10.1038/nrmicro2831

Prasanna, R., Chaudhary, V., Gupta, V., Babu, S., Kumar, A., Singh, R., et al. (2013). Cyanobacteria mediated plant growth promotion and bioprotection against Fusarium wilt in tomato. Eur. J. Plant Pathol. 136, 337-353. doi: 10. 1007/s10658-013-0167-x

Prasanna, R., Kanchan, A., Ramakrishnan, B., Ranjan, K., Venkatachalam, S., Hossain, F., et al. (2016). Cyanobacteria-based bioinoculants influence growth and yields by modulating the microbial communities favourably in the rhizospheres of maize hybrids. Eur. J. Soil Biol. 75, 15-23. doi: 10.1016/j.ejsobi. 2016.04.001

Prasanna, R., Nain, L., Ancha, R., Srikrishna, J., Joshi, M., and Kaushik, B. D. (2009). Rhizosphere dynamics of inoculated cyanobacteria and their growthpromoting role in rice crop. Egypt. J. Biol. 11, 26-36.

Prasanna, R., Nain, L., Tripathi, R., Gupta, V., Chaudhary, V., Middha, S., et al. (2008). Evaluation of fungicidal activity of extracellular filtrates of cyanobacteria-possible role of hydrolytic enzymes. J. Basic Microbiol. 48, 186194. doi: $10.1002 /$ jobm.200700199

Priya, H., Prasanna, R., Ramakrishnan, B., Bidyarani, N., Babu, S., Thapa, S., et al. (2015). Influence of cyanobacterial inoculation on the culturable microbiome and growth of rice. Microbiol. Res. 171, 78-89. doi: 10.1016/j.micres.2014.12.011

Pushkareva, E., Johansen, J. R., and Elster, J. (2016). A review of the ecology, ecophysiology and biodiversity of microalgae in Arctic soil crusts. Polar Biol. 39, 2227-2240. doi: 10.1007/s00300-016-1902-5

Rachidi, F., Benhima, R., Sbabou, L., and El Arroussi, H. (2020). Microalgae polysaccharides bio-stimulating effect on tomato plants: Growth and metabolic distribution. Biotechnol. Rep. 25:e00426. doi: 10.1016/j.btre.2020.e00426

Rana, A., Kabi, S. R., Verma, S., Adak, A., Pal, M., Shivay, Y. S., et al. (2015). Prospecting plant growth promoting bacteria and cyanobacteria as options for enrichment of macro-and micronutrients in grains in rice-wheat cropping sequence. Cogent Food Agricult. 1:1037379. doi: 10.1080/23311932. 2015.1037379

Rasmussen, U., Johansson, C., Renglin, A., Petersson, C., and Bergman, B. (1996). A molecular characterization of the Gunnera-Nostoc symbiosis: comparison with Rhizobium-and Agrobacterium-plant interactions. N. Phytol. 133, 391398. doi: 10.1111/j.1469-8137.1996.tb01906.x

Renuka, N., Prasanna, R., Sood, A., Ahluwalia, A. S., Bansal, R., Babu, S., et al. (2016). Exploring the efficacy of wastewater-grown microalgal biomass as a biofertilizer for wheat. Environ. Sci. Poll. Res. 23, 6608-6620. doi: 10.1007/ s11356-015-5884-6

Robbins, W. J., Hervey, A., and Stebbins, M. E. (1951). Further observations on Euglena and B12. Bull. Torrey Bot. Club 78, 363-375. doi: 10.2307/2482017

Rodgers, G., Bergman, B., Henriksson, E., and Udris, M. (1979). Utilisation of bluegreen algae as biofertilisers. Plant Soil 52, 99-107. doi: 10.1007/BF02197736

Rodríguez, A., Stella, A., Storni, M., Zulpa, G., and Zaccaro, M. (2006). Effects of cyanobacterial extracellular products and gibberellic acid on salinity tolerance in Oryza sativaL. Saline Syst. 2:7. doi: 10.1186/1746-1448-2-7

Sangha, J. S., Kandasamy, S., Khan, W., Bahia, N. S., Singh, R. P., Critchley, A. T., et al. (2015). $\lambda$-carrageenan suppresses tomato chlorotic dwarf viroid (TCDVd) replication and symptom expression in tomatoes. Mar. Drugs 13, 2875-2889. doi: $10.3390 / \mathrm{md} 13052875$

Sangha, J. S., Ravichandran, S., Prithiviraj, K., Critchley, A. T., and Prithiviraj, B. (2010). Sulfated macroalgal polysaccharides $\lambda$-carrageenan and $\iota$-carrageenan differentially alter Arabidopsis thaliana resistance to Sclerotinia sclerotiorum. Physiol. Mol. Plant Pathol. 75, 38-45. doi: 10.1016/j.pmpp.2010.08.003

Santi, S., De Marco, F., Polizzotto, R., Grisan, S., and Musetti, R. (2013). Recovery from stolbur disease in grapevine involves changes in sugar transport and metabolism. Front. Plant Sci. 4:171. doi: 10.3389/fpls.2013.00171

Santos, C. A., and Reis, A. (2014). Microalgal symbiosis in biotechnology. Appl. Microbiol. Biotechnol. 98, 5839-5846. doi: 10.1007/s00253-014-5764-x 
Sathiyamoorthy, P., and Shanmugasundaram, S. (1996). Preparation of cyanobacterial peptide toxin as a biopesticide against cotton pests. Appl. Microbiol. Biotechnol. 46, 511-513. doi: 10.1007/s002530050852

Schaller, G. E., Street, I. H., and Kieber, J. J. (2014). Cytokinin and the cell cycle. Curr. Opin. Plant Biol. 21, 7-15. doi: 10.1016/j.pbi.2014.05.015

Shaaban, M. M. (2001a). Green microalgae water extract as foliar feeding to wheat plants. Pak. J. Biol. Sci. 4, 628-632. doi: 10.3923/pjbs.2001.628.632

Shaaban, M. M. (2001b). Nutritional status and growth of maize plants as affected by green microalgae as soil additives. J. Biol. Sci. 1, 475-479. doi: 10.3923/jbs. 2001.475.479

Shah, A., and Vaidya, B. (1977). Detection of vitamin B 12 and pantothenic acid in cell exudates of blue-green algae. Biol. Plant. 19, 426-429. doi: 10.1007/ BF02922978

Shahri, W., and Tahir, I. (2014). Flower senescence: some molecular aspects. Planta 239, 277-297. doi: 10.1007/s00425-013-1984-z

Sharma, V., Prasanna, R., Hossain, F., Muthusamy, V., Nain, L., et al. (2020). Priming maize seeds with cyanobacteria enhances seed vigour and plant growth in elite maize inbreds. 3 Biotech. 10, 1-15. doi: 10.1007/s13205-0202141-6

Shukla, P. S., Borza, T., Critchley, A. T., and Prithiviraj, B. (2016). Carrageenans from red seaweeds as promoters of growth and elicitors of defense response in plants. Front. Mar. Sci. 3:81. doi: 10.3389/fmars.2016.00081

Silverster, W., and Smith, D. (1969). Nitrogen fixation by Gunnera-Nostoc symbiosis. Nature 224, 1231-1231. doi: 10.1038/2241231a0

Silvester, W. B. (1976). "Endophyte adaptation in Gunnera-Nostocsymbiosis," in Symbiotic Nitrogen Fixation in Plants, Vol. 7, ed. S. Nutman (Cambridge: Cambridge University Press), 521-538.

Singh, P., and Bisoyi, R. (1989). Blue green algae in rice fields. Phykos 28, 181-195.

Singh, S., and Datta, P. (2007). Outdoor evaluation of herbicide resistant strains of Anabaena variabilis as biofertilizer for rice plants. Plant Soil 296, 95-102. doi: 10.1007/s11104-007-9293-6

Song, G. C., Choi, H. K., and Ryu, C.-M. (2013). The folate precursor paraaminobenzoic acid elicits induced resistance against Cucumber mosaic virus and Xanthomonas axonopodis. Ann. Bot. 111, 925-934. doi: 10.1093/aob/ mct049

Spiller, H., Stallings, W., Woods, T., and Gunasekaran, M. (1993). Requirement for direct association of ammonia-excreting Anabaena variabilis mutant (SA-1) with roots for maximal growth and yield of wheat. Appl. Microbiol. Biotechnol. 40, 557-566. doi: 10.1007/BF00175748

Stirk, W. A., Ördög, V., Novák, O., Rolč́́k, J., Strnad, M., Bálint, P., et al. (2013). Auxin and cytokinin relationships in 24 microalgal strains1. J. Phycol. 49, 459-467. doi: 10.1111/jpy.12061

Stirk, W., Ördög, V., Van Staden, J., and Jäger, K. (2002). Cytokinin-and auxinlike activity in Cyanophyta and microalgae. J. Appl. Phycol. 14, 215-221. doi: 10.1023/A:1019928425569

Strzelczyk, E., Dahm, H., and Pachlewski, R. (1991). B-group vitamins production by mycorrhizal fungi in response to $\mathrm{pH}$ (in vitro studies). Plant Soil 137, 237-241. doi: 10.1007/BF00011202

Taheri, P., and Hofte, M. (2007). Induction of systemic defense responses in rice against the sheath blight pathogen Rhizoctonia solani, by means of riboflavin. Commun. Agricult. Appl. Biol. Sci. 72:983.

Taheri, P., and Tarighi, S. (2010). Riboflavin induces resistance in rice against Rhizoctonia solani via jasmonate-mediated priming of phenylpropanoid pathway. J. Plant Physiol. 167, 201-208. doi: 10.1016/j.jplph.2009.08.003

Tchan, Y. T., Kennedy, I. R. (1989). IR Possible N_2-fixing root nodules induced in non-legumes. Agric. Sci. 2, 57-59.

Treves, H., Raanan, H., Kedem, I., Murik, O., Keren, N., Zer, H., et al. (2016). The mechanisms whereby the green alga Chlorella ohadii, isolated from desert soil crust, exhibits unparalleled photodamage resistance. N. Phytol. 210, 1229-1243. doi: $10.1111 / \mathrm{nph} .13870$
Tripathi, R., Dwivedi, S., Shukla, M., Mishra, S., Srivastava, S., Singh, R., et al. (2008). Role of blue green algae biofertilizer in ameliorating the nitrogen demand and fly-ash stress to the growth and yield of rice (Oryza sativa L.) plants. Chemosphere 70, 1919-1929. doi: 10.1016/j.chemosphere.2007.07.038

Tsavkelova, E., Klimova, S. Y., Cherdyntseva, T., and Netrusov, A. (2006). Microbial producers of plant growth stimulators and their practical use: a review. Appl. Biochem. Microbiol. 42, 117-126. doi: 10.1134/S0003683806020013

van Loon, L. C., Geraats, B. P., and Linthorst, H. J. (2006). Ethylene as a modulator of disease resistance in plants. Trends Plant Sci. 11, 184-191.

Vera, J., Castro, J., Contreras, R. A., González, A., and Moenne, A. (2012). Oligo-carrageenans induce a long-term and broad-range protection against pathogens in tobacco plants (var. Xanthi). Physiol. Mol. Plant Pathol. 79, 31-39.

Volk, R.-B., and Furkert, F. H. (2006). Antialgal, antibacterial and antifungal activity of two metabolites produced and excreted by cyanobacteria during growth. Microbiol. Res. 161, 180-186.

Watanabe, F., and Bito, T. (2018). Vitamin B12 sources and microbial interaction. Exp. Biol. Med. 243, 148-158.

Welchen, E., Schmitz, J., Fuchs, P., García, L., Wagner, S., Wienstroer, J., et al. (2016). D-Lactate dehydrogenase links methylglyoxal degradation and electron transport through cytochrome C. Plant Physiol. 172, 901-912.

Werner, T., Motyka, V., Strnad, M., and Schmülling, T. (2001). Regulation of plant growth by cytokinin. Proc. Natl. Acad. Sci. 98, 10487-10492.

Whipps, J., Lewis, K., and Cooke, R. (1988). "Mycoparasitism and plant disease control 161-187," in Fungi in Biological Control Systems, ed. N. M. Burge (Manchester: Manchester University Press), 176.

Wilpiszeski, R. L., Aufrecht, J. A., Retterer, S. T., Sullivan, M. B., Graham, D. E., Pierce, E. M., et al. (2019). Soil aggregate microbial communities: towards understanding microbiome interactions at biologically relevant scales. Appl. Environ. Microbiol. 85, 324-319e.

Wuang, S. C., Khin, M. C., Chua, P. Q. D., and Luo, Y. D. (2016). Use of Spirulina biomass produced from treatment of aquaculture wastewater as agricultural fertilizers. Algal Res. 15, 59-64.

Xu, J., Zhang, Y., Zhang, P., Trivedi, P., Riera, N., Wang, Y., et al. (2018). The structure and function of the global citrus rhizosphere microbiome. Nat. Commun. 9, 1-10.

Zhang, B., Zhang, Y., Downing, A., and Niu, Y. (2011). Distribution and composition of cyanobacteria and microalgae associated with biological soil crusts in the Gurbantunggut Desert, China. Arid Land Res. Manag. 25, 275-293.

Zhang, J., Wang, X., and Zhou, Q. (2017). Co-cultivation of Chlorella spp and tomato in a hydroponic system. Biomass Bioener. 97, 132-138.

Zhu, H., Li, S., Hu, Z., and Liu, G. (2018). Molecular characterization of eukaryotic algal communities in the tropical phyllosphere based on real-time sequencing of the 18S rDNA gene. BMC Plant Biol. 18, 1-14. doi: 10.1186/s12870-018-1588-7

Zou, P., Lu, X., Zhao, H., Yuan, Y., Meng, L., Zhang, C., et al. (2019). Polysaccharides derived from the brown algae Lessonia nigrescens enhance salt stress tolerance to wheat seedlings by enhancing the antioxidant system and modulating intracellular ion concentration. Front. Plant Sci. 10:48. doi: $10.3389 /$ fpls.2019.00048

Conflict of Interest: The authors declare that the research was conducted in the absence of any commercial or financial relationships that could be construed as a potential conflict of interest.

Copyright (c) 2021 Lee and Ryu. This is an open-access article distributed under the terms of the Creative Commons Attribution License (CC BY). The use, distribution or reproduction in other forums is permitted, provided the original author(s) and the copyright owner(s) are credited and that the original publication in this journal is cited, in accordance with accepted academic practice. No use, distribution or reproduction is permitted which does not comply with these terms. 